\title{
New record of the soft-bodied genus Franciscideres (Kinorhyncha) from Argentina, with notes on its movement and morphological variation
}

\author{
KEVIN A. RUCCI ${ }^{1,2 *}$, BIRGER NEUHAUS ${ }^{3}$, VERÓNICA N. BULNES ${ }^{4} \&$ NÉSTOR J. CAZZANIGA $^{1,5}$ \\ ${ }^{1}$ Departamento de Biología, Bioquímica y Farmacia, Universidad Nacional del Sur, San Juan 670, B8000ICN Bahia Blanca, Buenos \\ Aires, Argentina. \\ ${ }^{2} \equiv=$ kevin.rucci.224@gmail.com; ® https://orcid.org/0000-0002-0940-2423; Tel: +54 0291-4595101 2422 \\ ${ }^{3}$ Museum für Naturkunde Berlin - Leibniz Institute for Evolution and Biodiversity Science, Invalidenstr. 43, D-10115 Berlin, Germany. \\ ="birger.neuhaus@mfn.berlin \\ ${ }^{4}$ INBIOSUR, CONICET, San Juan 671, B8000ICN Bahía Blanca, Buenos Aires, Argentina

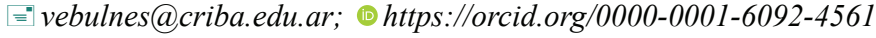 \\ ${ }^{5}$ !"ficazzan@criba.edu.ar; 10 https://orcid.org/0000-0001-6570-0153 \\ *Corresponding author
}

\begin{abstract}
Samples collected from Monte Hermoso, Buenos Aires Province, Argentina revealed the presence of specimens of the genus Franciscideres Dal Zotto et al., 2013, previously known only from Brazil. This morphotype seems to differ from the only known species, Franciscideres kalenesos Dal Zotto et al., 2013, in the following characters: (1) presence of ventrolateral tubes on segment 1, (2) introvert features, (3) each segment composed of a closed cuticular ring, (4) trunk cuticle ornamented by a secondary fringe of knob-like structures, (5) posterior margin of segment 10 ventrally terminating in two lateral and one broad triangular lobes, (6) posterior margin of segment 11 centrally terminating in four lobes (7) lateral terminal spines armed with thorn-like processes, (8) pores/sensory spots/gland cells distribution and (9) sexual dimorphism in segments 10 and 11. Because of the lack of full information about $F$. kalenesos from Brazil, we consider the new exemplars as Franciscideres cf. kalenesos. Additionally, we provide new information about the movement of this species using light microscopy and we compare these movements with those of other meiofaunal inhabitants.
\end{abstract}

Key words: Buenos Aires province, intertidal, meiobenthos, taxonomy, intraspecific variation

\section{Introduction}

Knowledge of the Kinorhyncha thriving in the Southwestern Atlantic is actually defective since only ten species were identified over the $\sim 12000 \mathrm{~km}$ of continental shores of Brazil and Argentina. Seven of these species were described as new in the last 15 years (Table 1) and there is still a large latitude gap $\left(19^{\circ}\right.$ or $\left.\sim 2500 \mathrm{~km}\right)$ between the

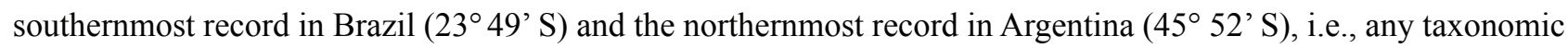
information on kinorhynchs is lacking from the whole ecoregions of Rio Grande, Uruguay and Buenos Aires within the Warm Temperate Southwestern Atlantic Province (Spalding et al. 2007; Miloslavich et al. 2011).

Only five species of Kinorhyncha are known from the continental Argentinian shores. Echinoderes pilosus was reported by Pallares (1966) from red algae washes and plankton samples from Puerto Deseado in southern Patagonia. No other references were published up to Martorelli and Higgins (2004) who reported four other species found in the stomach contents of the prawn Pleoticus muelleri from Comodoro Rivadavia in the central San Jorge gulf (Patagonia). The specific search of kinorhynchs was clearly neglected in Argentina and probably their biodiversity was strongly underestimated.

The first aim of this article is to describe the morphology of an unusual kinorhynch with a thin body cuticle, collected from a sandy beach at Monte Hermoso (Buenos Aires Province, Argentina). Our material showed the characters defining the monotypical genus Franciscideres Dal Zotto et al., 2013. The specific identification faces the taxonomical conflict arising from the insufficiency of the original information about the type species and the recent 
evidence that Kinorhyncha species can show a considerably larger intraspecific variability than previously assumed (Neuhaus \& Sørensen 2013; Neuhaus \& Kegel 2015; Neuhaus et al. 2014, 2019; Sánchez et al. 2019; Yamasaki \& Dal Zotto 2019). Though intraspecific variation was rarely thought to be important for the taxonomy of kinorhynchs (Sørensen \& Pardos 2008; Dal Zotto et al. 2013; Neuhaus 2013; Yamasaki 2016, 2017), the huge variation described for some species (e.g., Neuhaus et al. 2019; Sánchez et al. 2019) highlights a change of mind and emphasizes the need of paying attention to such variation.

TABLE 1. Species of Kinorhyncha known to live in the South Western Atlantic continental coasts, ordered according to latitude.

Brazil

\begin{tabular}{|c|c|c|}
\hline Species & Localities & Sources \\
\hline $\begin{array}{l}\text { Cateria styx } \\
\text { Gerlach, } 1956\end{array}$ & $\begin{array}{l}\left.\text { Macaé beach (LT: } 22^{\circ} 22^{\prime} \mathrm{S}\right) \text {, Rio de Janeiro State; Cavaleiros beach } \\
\text { (Macaé); Ubatuba }\left(23^{\circ} 26^{\prime} \mathrm{S}\right) \text {, São Paulo State }\end{array}$ & $\begin{array}{l}\text { Gerlach 1956; Hig- } \\
\text { gins } 1968\end{array}$ \\
\hline $\begin{array}{l}\text { Franciscideres kalenesos } \\
\text { Dal Zotto et al., } 2013\end{array}$ & $\begin{array}{l}\text { Ilhabela (LT: } 23^{\circ} 46^{\prime} \text { S) and Boissucanga beach }\left(23^{\circ} 47^{\prime} \text { S), São Se- }\right. \\
\text { bastião, São Paulo State; Balneário Nereidas, Guaratuba }\left(25^{\circ} 55^{\prime} \mathrm{S}\right) \text {, } \\
\text { Paraná State; Navegantes beach }\left(26^{\circ} 54^{\prime} \mathrm{S}\right) \text {, Santa Catarina State }\end{array}$ & $\begin{array}{l}\text { Dal Zotto et al. } \\
\text { 2013; Lopez Mello } \\
\text { 2017, } 2019\end{array}$ \\
\hline $\begin{array}{l}\text { Echinoderes astridae } \\
\text { Sørensen, } 2014\end{array}$ & São Sebastião (LT: $23^{\circ} 48^{\prime}$ S) & Sørensen 2014 \\
\hline $\begin{array}{l}\text { Echinoderes ajax } \\
\text { Sørensen, } 2014\end{array}$ & São Sebastião (LT: 23ํ4’ S) & Sørensen 2014 \\
\hline $\begin{array}{l}\text { Echinoderes marthae } \\
\text { Sørensen, } 2014\end{array}$ & São Sebastião (LT: $23^{\circ} 49^{\prime}$ S) & Sørensen 2014 \\
\hline
\end{tabular}

\begin{tabular}{|c|c|c|}
\hline Species & Localities & Sources \\
\hline $\begin{array}{l}\text { Franciscideres cf. kalenesos } \\
\text { Dal Zotto et al., } 2013\end{array}$ & Monte Hermoso beach ( $\left.38^{\circ} 59^{\prime} \mathrm{S}\right)$, Buenos Aires Province & This study \\
\hline $\begin{array}{l}\text { Echinoderes pilosus } \\
\text { Lang, } 1949\end{array}$ & Puerto Deseado $\left(47^{\circ} 45^{\prime} \mathrm{S}\right)$, Santa Cruz Province & Pallares 1966 \\
\hline $\begin{array}{l}\text { Condyloderes storchi } \\
\text { Higgins, } 2004 \text { in Martorelli } \\
\text { \& Higgins, } 2004\end{array}$ & Comodoro Rivadavia (LT: $45^{\circ} 52^{\prime} \mathrm{S}$ ), Chubut Province & $\begin{array}{l}\text { Martorelli \&Hig- } \\
\text { gins } 2004\end{array}$ \\
\hline $\begin{array}{l}\text { Krakenella argentinensis (Mar- } \\
\text { torelli \& Higgins, 2004) }\end{array}$ & 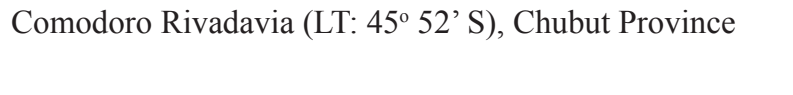 & $\begin{array}{l}\text { Martorelli \& Hig- } \\
\text { gins } 2004\end{array}$ \\
\hline $\begin{array}{l}\text { Pycnophyes neuhausi } \\
\text { Higgins, } 2004 \text { in Martorelli \& } \\
\text { Higgins, } 2004\end{array}$ & Comodoro Rivadavia (LT: $45^{\circ} 52^{\prime} \mathrm{S}$ ), Chubut Province & $\begin{array}{l}\text { Martorelli \& Hig- } \\
\text { gins } 2004\end{array}$ \\
\hline $\begin{array}{l}\text { Cristaphyes anomalus } \\
\text { (Lang, 1953) }\end{array}$ & Comodoro Rivadavia ( $45^{\circ} 52^{\prime} \mathrm{S}$ ), Chubut Province & $\begin{array}{l}\text { Martorelli \& Hig- } \\
\text { gins } 2004\end{array}$ \\
\hline
\end{tabular}

Franciscideres includes only the type species, F. kalenesos Dal Zotto et al., 2013 from Brazil. The specimens collected in Argentina may belong to the same or to a very close species, but this uncertainty cannot be overcome currently, because several characters seen in our material were not described for the type material, and several detected differences are suspected to probably fit the range of intraspecific variation. So, to advance a description of the Argentinian specimens without a definitive identification, seems to be the most parsimonious outcome, pending a more complete and detailed study of new material from the original description area.

A second aim of this paper is to inform and film how living specimens achieve their locomotive movements. Movement of Kinorhyncha was rarely described and the main focus was on less flexible species having a thick cuticle (Neuhaus 2013); the movement of kinorhynchs showing a slender trunk with a thin body cuticle, like those 
studied here, has been hypothesized before on the basis of an analysis of their morphology (Neuhaus \& Kegel 2015 for species of Cateria) and was observed recently for Cateria styx Gerlach, 1956 by Herranz et al. (2019).

\section{Materials and methods}

Study area. Monte Hermoso city $\left(38^{\circ} 56^{\prime} 33^{\prime \prime} \mathrm{S}, 61^{\circ} 15^{\prime} 55^{\prime}\right.$ W) is located in the South of Buenos Aires province, Argentina, between Sauce Grande River mouth and Pehuen-Có town (Fig. 1). The coastal system is composed of a five kilometres-wide dune belt and an east-west oriented beach, exposed to the direct action of waves coming from the South (Caló et al. 1995). Tides are the semidiurnal-type, with an average amplitude of 2.43 meters. Wind blows mainly from the North (Caló et al. 2005). Coastline substrate presents a fine to medium granulometry $(0.21$ to $0.32 \mathrm{~mm}$ ), grains smaller than $0.063 \mathrm{~mm}$ are almost missing. Average annual temperature ranges between $6{ }^{\circ} \mathrm{C}$ in winter and $19{ }^{\circ} \mathrm{C}$ in Summer (Fiori 2002). Combined wave traits and sediment type generates a dissipative-type beach (Caló et al. 1995).

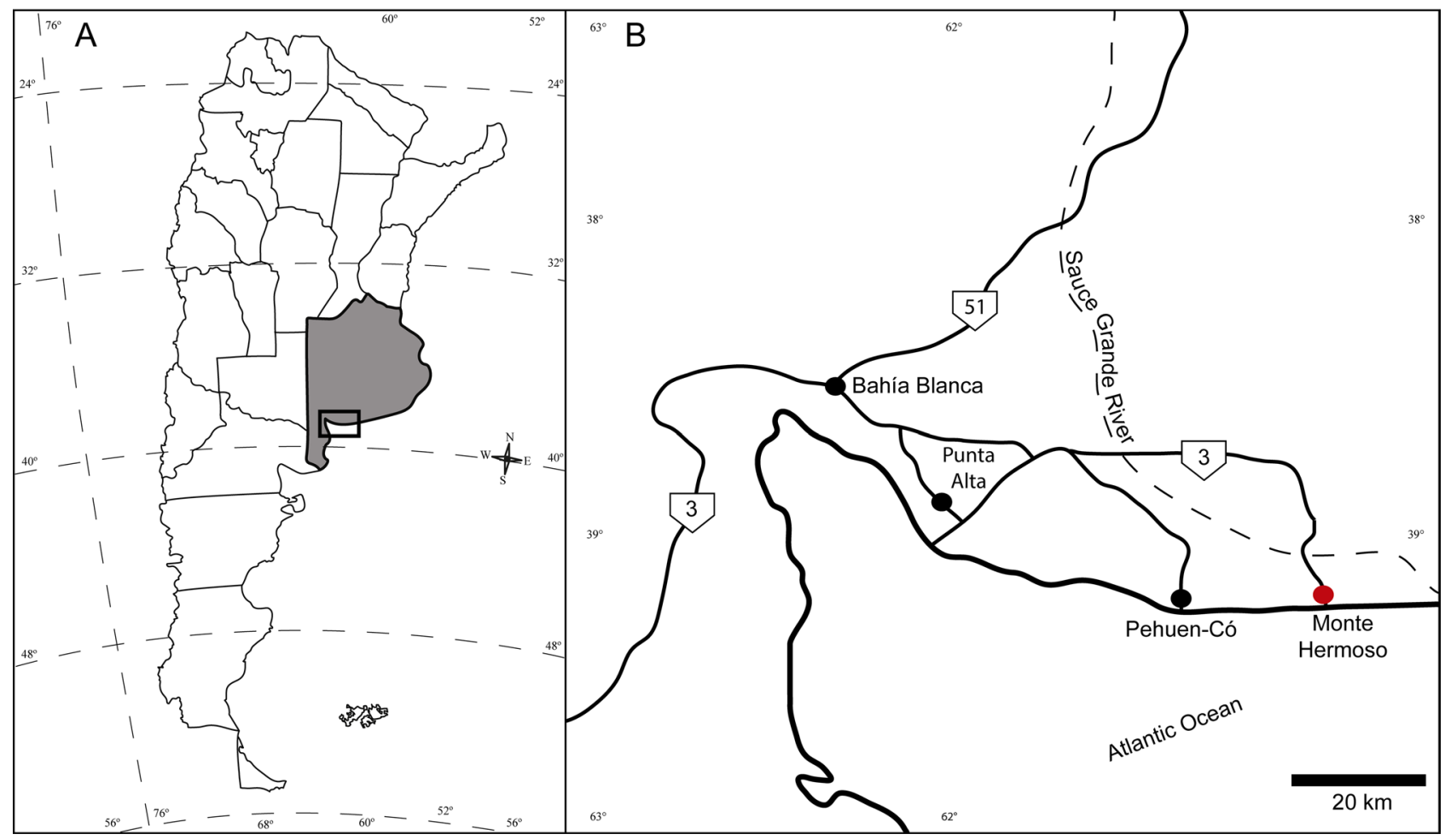

FIGURE 1. Maps showing the sampling locality of Franciscideres cf. kalenesos A. Map of Argentina showing Buenos Aires province in grey. B. Enlargement of the rectangle in A, with Monte Hermoso indicated by a red spot.

Sampling and processing. Sediment samples were collected on April 28 and May 18, 2015, May 17, 2016, August 1, 2017, March 21 and November 13, 2018. Sand was picked at 2-3 cm depth at the coastline during low tide near the waterline and stored in plastic containers, transported and processed in the laboratory. Specimens were extremely sticky and often covered with detritus, which hampered SEM observations considerably. For this reason, 18 out of 37 specimens mounted for SEM in Berlin could not be assigned to sex and were identified as adults.

Samples were fixed in $5 \%$ formaldehyde or examined in vivo after a preliminary treatment with a $7 \% \mathrm{MgCl}_{2}$ solution. Meiofauna was extracted from samples by the elutriation/ decantation method and sifted using a $37 \mu \mathrm{m}$ sieve (Giere 2009). Afterwards, kinorhynchs were sorted under a dissecting microscope, transferred to a freshwater solution for 30 minutes and preserved in $5 \%$ formaldehyde. Specimens for light microscopy (LM) were transferred to a glycerine-alcohol $70 \%(1: 1)$ solution and mounted in glycerine. The specimens were examined and photographed using Nomarski differential interference contrast with a Nikon ECLIPSE TE300 microscope equipped with a Nikon DIGITAL SIGHT DS-U2 camera or with a Zeiss Axioplan 2 mot equipped with a digital camera Zeiss AxioCam MRc5 and objectives Plan-Apochromat 20x/0.60, 63x/1.40 DIC Oil, and 100x/1.40 Oil as well as Plan-Neofluar 40x/1.30 Oil. Exemplars examined in vivo were recorded using a digital videocamera attached to the 
light microscope. Specimens for scanning electron microscope (SEM) were fixed in $5 \%$ formaldehyde, dehydrated through a graded series of ethanol, cleared in acetone, and critical point-dried with a Polaron E3000 using $\mathrm{CO}_{2}$. The dried specimens were mounted on aluminum stubs, sputter coated with gold by a Pelco 91000 Model 3 and examined with a Zeiss LEO EVO 40 scanning electron microscope $(7.0 \mathrm{kV})$. Additional specimens were postfixed with $\mathrm{OsO}_{4}$ in $0.67 \mathrm{M}$ phosphate buffer $(\mathrm{pH}=7.3)$ for 2 hours, dehydrated through a graded series of ethanol, critical-point dried with a Leica EM CPD30, mounted on aluminum stubs, sputter coated with gold (Quantum Quorum Q150R S), and investigated in a Zeiss EVO LS 10 or a Jeol JSM-6610 LV scanning electron microscope. Drawings were made using Wacom Bamboo@ Connect graphic tablet and Adobe $\subset$ Illustrator software.

A

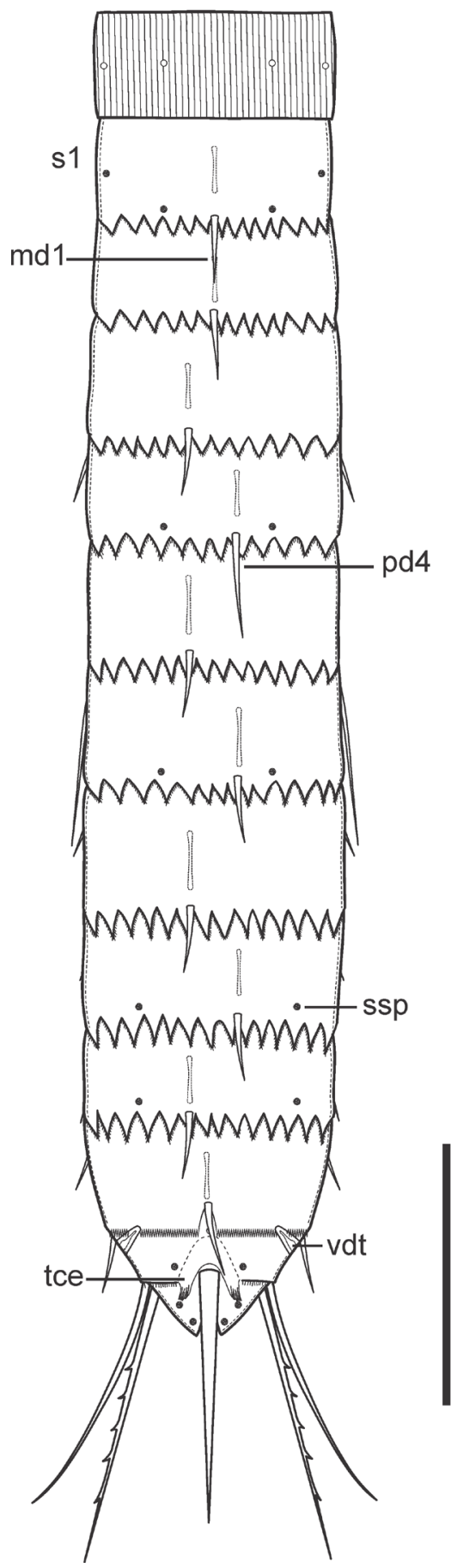

B

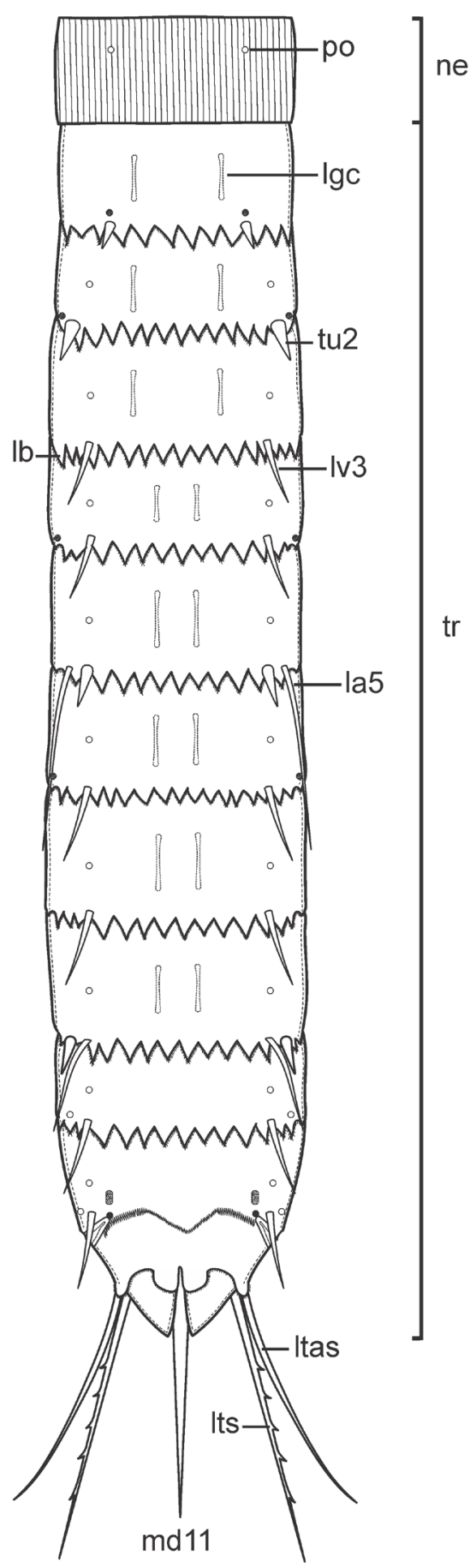

C

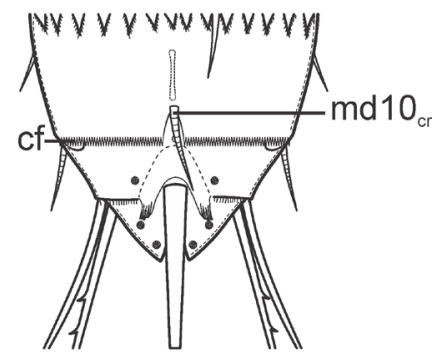

$\mathrm{D}$

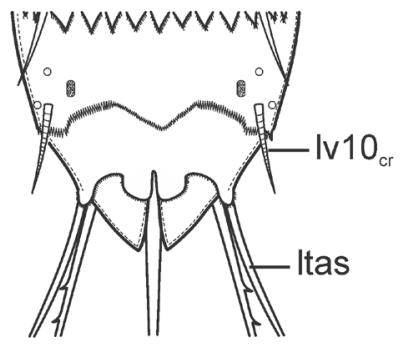

FIGURE 2. Line art illustrations of Franciscideres cf. kalenesos. A. Female, dorsal view. B. Female, ventral view. C. Male, segments 10 and 11, dorsal view. D. Male, segments 10 and 11, ventral view. Scale bar: $100 \mu \mathrm{m}$. 


\section{List of abbreviations}

btl broad triangular lobe of segment 10

cf male-specific cuticular flap

$\mathrm{cl}_{11} \quad$ central lobe of segment 11

cr crenulate

cs cuticular spinose processes anterior of primary spinoscalids

f female character

fcp mouth cone fringe with cuticular processes

go gonopore

ios1 type-1 inner oral style

Is introvert sector

la lateral accessory

la5 lateral accessory spine on segment 5

$\mathrm{lb} \quad$ posterior lobes of a segment

ld laterodorsal

le/ri left/right

lge longitudinal gland cell

$1 l_{10} \quad$ lateral lobe of segment 10

LT type locality

ltas lateral terminal accessory spine

lts lateral terminal spine

lv lateroventral

lv3 lateroventral spine on segment 3

$\operatorname{lv} 10_{\text {cr }}$ crenulate lateroventral spine on segment 10

$\mathrm{m}$ male character

MACN Museo Argentino de Ciencias Naturales "Bernardino Rivadavia"

md middorsal

md1 middorsal spine on segment 1

$\mathrm{ml}$ midlateral

n.a. not available

no notch

ne neck

ocs ornamentation of cuticular spinose processes

oos outer oral style

pd paradorsal

pd3 paradorsal spine on segment 3

ph pharynx

po pore

psc primary spinoscalid

$\mathrm{psc}_{1} \quad$ long primary spinoscalids

$\mathrm{psc}_{\mathrm{sh}} \quad$ short primary spinoscalids

pv paraventral

s spine

s1 segment 1

sd subdorsal

sf secondary fringe

sh short

sl sublateral

ssp type-1 sensory spot

tce trunk cuticle elevation anterior of middorsal spine on segment 11

tl trunk length 
$\operatorname{tr}$

tss

tt

tu1

vdt

v1

W

ZMB

trunk

subcuticular tubes of a sensory spot

triangular terminal extensions of segment 11

tube on segment 1

female-specific tubular structure on segment 10

ventrolateral

mouth cone weir

Museum für Naturkunde Berlin (previously Zoological Museum Berlin)

\title{
Results
}

\section{Systematics}

Class Allomalorhagida Sørensen et al., 2015

Family Franciscideridae Sørensen et al., 2015

\author{
Genus Franciscideres Dal Zotto et al., 2013
}

Franciscideres cf. kalenesos Dal Zotto et al., 2013 from Argentina

Material examined. Material deposited in the MACN, Autonomous City of Buenos Aires (Argentina): 15 females and six males all collected in 2015, 2017 and 2018, mounted in glycerine and deposited under catalogue number MACN-In 43236a-g, MACN-In 43237a and MACN-In 43238a-m. Twelve adults collected on 2017, mounted for SEM and deposited under catalogue number MACN-In 43239a-e.

Material deposited in the ZMB, Berlin (Germany): 15 females and 11 males collected in 2016 and 2018, mounted in paraffin-glycerine and deposited under catalogue numbers ZMB 11977-11979 and ZMB 12126-12148; 11 females, nine males and 17 adults collected in 2016, mounted for SEM and deposited under catalogue numbers ZMB 12149-12185.

All material deposited in Argentina and Germany were collected from the intertidal zone of Monte Hermoso beach.

Description. For a complete overview of measures and dimensions see Table 2. Distribution of cuticular structures, i.e., pores, sensory spots, gland cells, spines and tubes, is summarized in Table 3.

Mouth cone. The mouth cone is extremely long (Fig. 4D) and equipped with inner and outer oral styles (Figs 4D, 8B). There seem to be two different types of inner oral styles, one with a more or less constant tapering towards the tip and a second one which tapers abruptly. These styles alternate and must belong to two different rings (Fig. 8B). Under the light microscope inner oral styles are recognized as hook-like structures posterior of the outer oral styles. There exist nine rigid outer oral styles, each formed by a distal, a central spinose, and a basal rectangular element. The apical piece is the shortest and bends towards the mouth opening (Fig. 8B). The basal piece is sculptured with a fringe composed of five anteriorly oriented short spinose processes (Fig. 4D). Neighbouring styles alternate slightly in length. A mouth cone weir formed by plicated cuticle appearing as ridges can be recognized inside the mouth cone (Fig. 8B).

Introvert. The introvert appears to be equipped with six rings of scalids (Figs 3, 8C,D). The anteriormost ring is composed of 10 primary spinoscalids. Five of these scalids are longer than the remaining five (Figs 4B,C,E, 8B). Scalids of ring 01 are smooth, appear to be annulated apically and terminate distally in a blunt tip (Fig. 9B). Anterior of the primary spinoscalids occurs a ring of 10 pairs of thin cuticular spinose processes (Figs 3, 4B-E, 8D). Each pair of these spine-like processes is fused at its base, where a pair of short cuticular spinose structures is discernible. Lateral hairs appear along these 10 pairs of cuticular spinose processes (Figs 4B,C, 8C,D). Due to their position (anterior of the primary spinoscalids), these spines are interpreted as elongated cuticular hairs of the scalids. The ring 02 comprises 10 long spinoscalids with a basal sheath (Figs 3, 4C, 8C,D). The ring 03 is equipped with 20 very short spinoscalids each emerging laterally from its basal sheath, which terminates in a few cuticular hairs. Each of the rings 04-06 possesses 10 spinoscalids with a basal sheath, longer than those of ring 03 and with the typical 


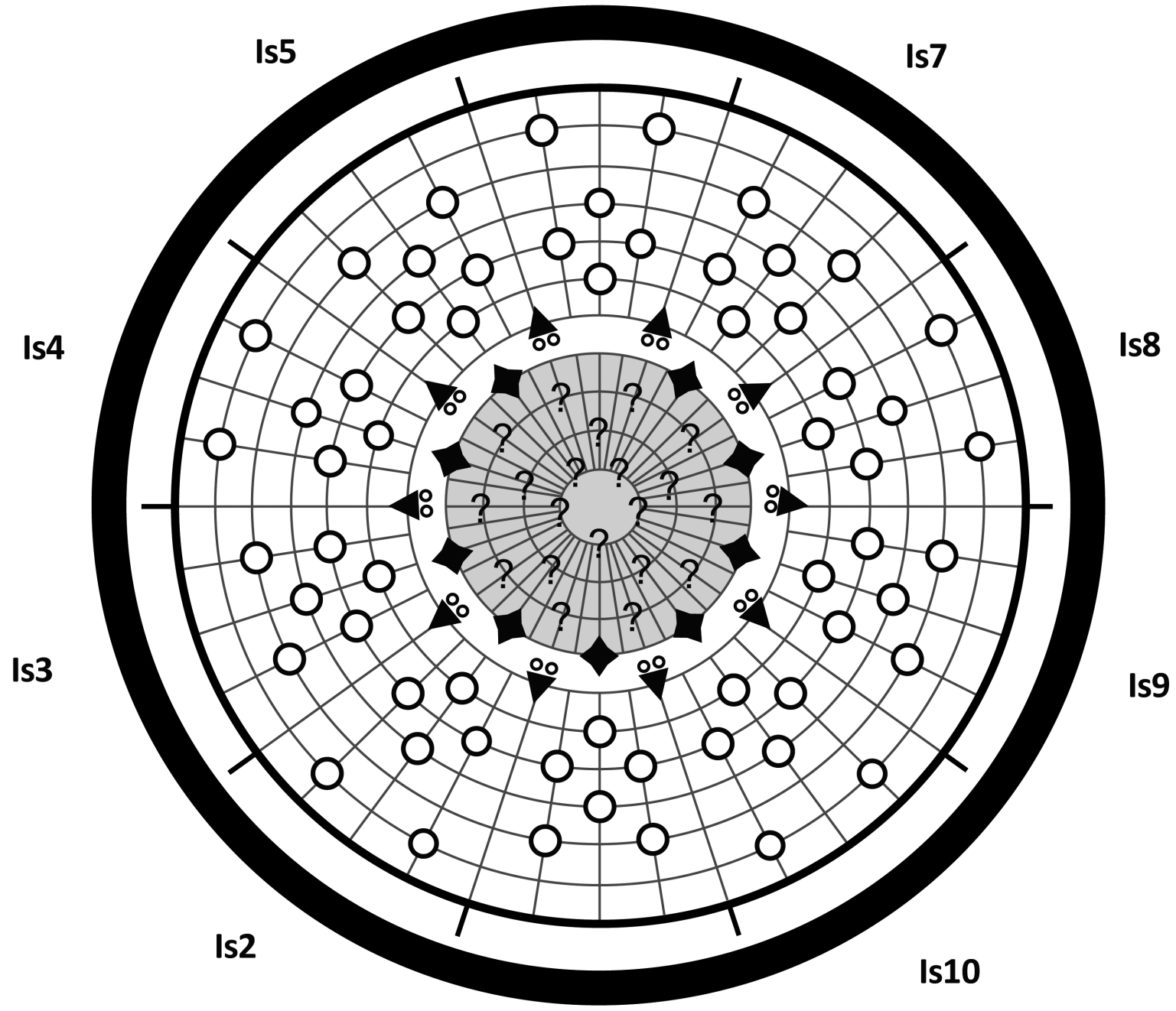

Is1

Scalid and style arrangement

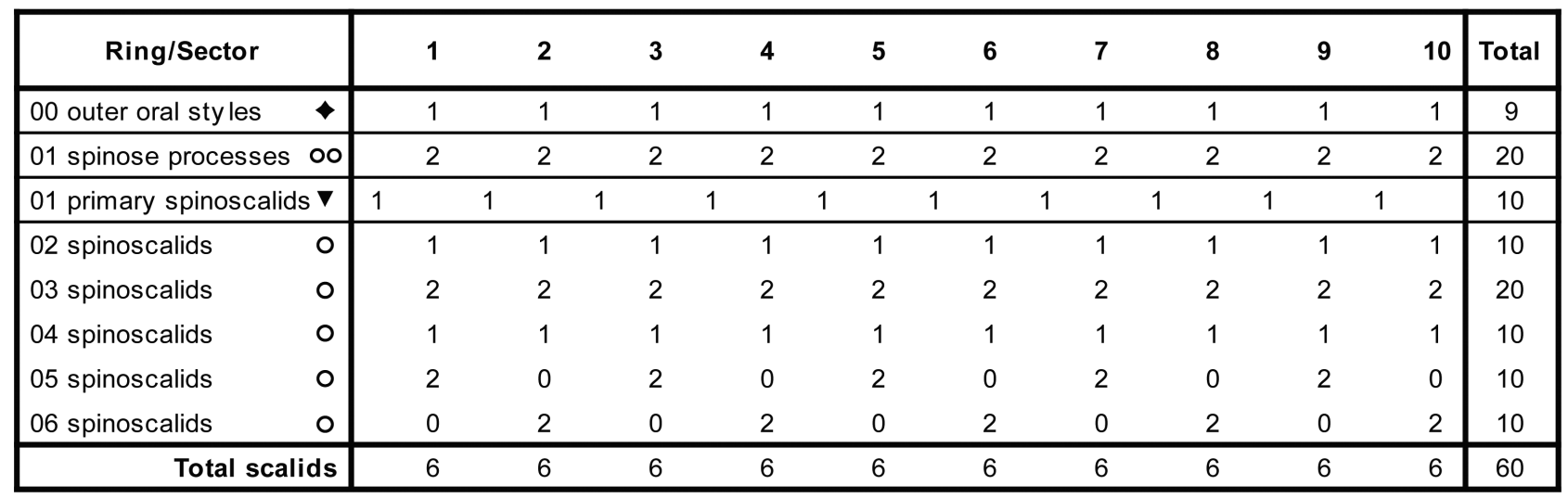

FIGURE 3. Diagram of mouth cone (grey area), introvert and placids of Franciscideres cf. kalenesos, showing distribution of outer oral styles, spinose processes and spinoscalids. The table below shows the scalid arrangement by sector (Is1 to Is10). Question marks indicate the uncertain arrangement of inner oral styles. 


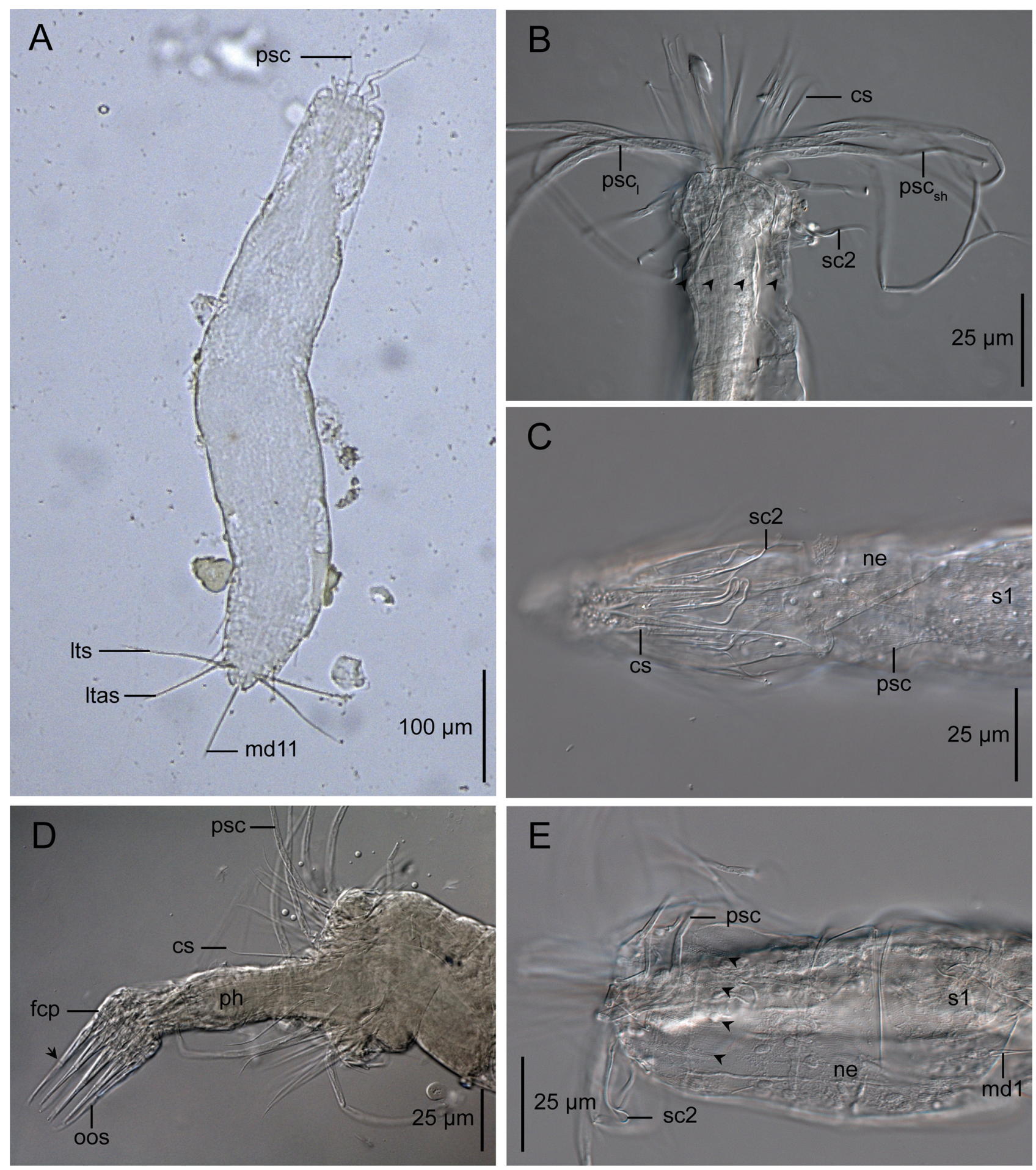

FIGURE 4. Light micrographs showing habitus and detailed morphology of the head of Franciscideres cf. kalenesos. Female (A-D) and male (E), in ventral (A, C), dorsal (E) and lateral view (B, D). A. Overview of adult specimen [MACN-In 43238i]. B, C. Detail of introvert [ZMB 11977, 12143]. D. Protruded mouth cone with joint between basal and central style elements (arrow) [MACN-In 43237a]. E. Introvert and anterior part of trunk [ZMB 11979]. Arrowheads mark the position of cuticular fields of short hairs posterior of the posteriormost ring of spinoscalids.

appearance of a spinoscalid (Figs 3, 8C). The arrangement of scalids in odd and even sectors is difficult to elucidate, because in several specimens both sectors seem to possess the same arrangement of scalids. However, more favourite specimens reveal in the even sectors that the posteriormost ring gets free more posteriorly than in the odd sectors 
seeming that this is actually the sixth ring (Figs 3, 8C). Trichoscalids were not observed. Behind rings 05 and 06,14 cuticular fields are observed. These areas are covered with short cuticular hairs, appearing as fine 'denticles' in light microscopy (Figs 4B,E, 5A, 6A, 8C).

TABLE 2. Measurements from light microscopy of adult Franciscideres $\mathrm{cf}$. kalenesos from Argentina, including number of measured specimens (n), standard deviation (SD) and coefficient of variation (CV).

\begin{tabular}{|c|c|c|c|c|c|c|c|c|c|c|}
\hline \multirow[t]{2}{*}{ Character $(\mu \mathrm{m})$} & \multicolumn{2}{|c|}{$\mathrm{n}$} & \multicolumn{2}{|c|}{ Range } & \multicolumn{2}{|c|}{ Mean } & \multicolumn{2}{|c|}{ SD } & \multicolumn{2}{|c|}{$\mathrm{CV}$} \\
\hline & $\mathrm{f}$ & $\mathrm{m}$ & $\mathrm{f}$ & $\mathrm{m}$ & $\mathrm{f}$ & $\mathrm{m}$ & $\mathrm{f}$ & $\mathrm{m}$ & $\mathrm{f}$ & $\mathrm{m}$ \\
\hline $\mathrm{tl}$ & 14 & 6 & $498-629$ & $457-587$ & 569 & 527 & 46 & 60 & 0.08 & 0.11 \\
\hline neck & 3 & 4 & $61-84$ & $60-90$ & 71 & 74 & 12 & 13 & 0.17 & 0.17 \\
\hline s1 & 14 & 6 & $29-54$ & $32-46$ & 39 & 39 & 7 & 5 & 0.17 & 0.13 \\
\hline s2 & 13 & 5 & $31-49$ & $36-47$ & 42 & 43 & 5 & 5 & 0.11 & 0.11 \\
\hline s3 & 13 & 5 & $27-61$ & $39-61$ & 46 & 49 & 9 & 8 & 0.20 & 0.17 \\
\hline s4 & 13 & 5 & $36-66$ & $37-64$ & 52 & 56 & 10 & 11 & 0.20 & 0.20 \\
\hline s5 & 13 & 5 & $41-66$ & $44-63$ & 56 & 59 & 8 & 8 & 0.15 & 0.14 \\
\hline s6 & 13 & 6 & $50-66$ & $52-66$ & 59 & 58 & 6 & 6 & 0.10 & 0.10 \\
\hline s7 & 13 & 6 & $41-77$ & $42-70$ & 61 & 55 & 8 & 11 & 0.14 & 0.20 \\
\hline s8 & 13 & 6 & $45-67$ & $39-62$ & 60 & 49 & 6 & 10 & 0.10 & 0.20 \\
\hline s9 & 13 & 6 & $45-63$ & $36-58$ & 56 & 47 & 6 & 7 & 0.10 & 0.15 \\
\hline s10 & 13 & 6 & $37-66$ & $39-59$ & 51 & 46 & 9 & 7 & 0.17 & 0.16 \\
\hline s11 & 14 & 6 & $32-43$ & $35-47$ & 38 & 39 & 3 & 5 & 0.09 & 0.12 \\
\hline md1 (ac) & 14 & 6 & $8-16$ & $9-13$ & 13 & 11 & 2 & 2 & 0.17 & 0.16 \\
\hline $\mathrm{md} 2(\mathrm{ac})$ & 14 & 5 & $10-20$ & $13-18$ & 15 & 15 & 3 & 6 & 0.21 & 0.43 \\
\hline pd3 (ac) & 14 & 6 & $17-23$ & $18-22$ & 20 & 19 & 2 & 2 & 0.10 & 0.08 \\
\hline $\mathrm{pd} 4$ (ac) & 14 & 6 & $18-31$ & $21-26$ & 24 & 23 & 3 & 2 & 0.14 & 0.08 \\
\hline $\mathrm{pd} 5(\mathrm{ac})$ & 14 & 6 & $25-58$ & 54-62 & 32 & 58 & 11 & 3 & 0.34 & 0.05 \\
\hline pd6 (ac) & 14 & 6 & $25-60$ & $37-59$ & 33 & 51 & 10 & 8 & 0.31 & 0.15 \\
\hline $\mathrm{pd} 7$ (ac) & 14 & 6 & $24-50$ & $43-53$ & 33 & 48 & 7 & 4 & 0.21 & 0.07 \\
\hline pd8 (ac) & 14 & 6 & $27-41$ & $32-39$ & 33 & 37 & 4 & 3 & 0.13 & 0.07 \\
\hline pd9 (ac) & 14 & 6 & $26-45$ & $27-34$ & 32 & 30 & 5 & 2 & 0.14 & 0.08 \\
\hline md10 (f: ac, m: cr) & 14 & 5 & $18-31$ & 24-29 & 26 & 26 & 3 & 11 & 0.11 & 0.41 \\
\hline md11 (ac) & 14 & 6 & $56-85$ & 64-78 & 72 & 69 & 7 & 6 & 0.10 & 0.08 \\
\hline vl1 (tu) & n.a. & n.a. & n.a. & n.a. & n.a. & n.a. & n.a. & n.a. & n.a. & n.a. \\
\hline la2 (tu) & 12 & 5 & $9-14$ & $8-13$ & 11 & 10 & 1 & 2 & 0.12 & 0.19 \\
\hline $\operatorname{lv3}(\mathrm{ac})$ & 14 & 6 & $14-20$ & $14-20$ & 18 & 17 & 1 & 2 & 0.08 & 0.12 \\
\hline lv4 (ac) & 14 & 6 & 24-34 & $27-31$ & 29 & 30 & 3 & 2 & 0.11 & 0.05 \\
\hline $\operatorname{lv} 5(\mathrm{tu})$ & 14 & 6 & $12-17$ & $10-15$ & 14 & 13 & 1 & 2 & 0.09 & 0.14 \\
\hline la5 (ac) & 14 & 6 & $27-61$ & $55-62$ & 34 & 58 & 10 & 3 & 0.30 & 0.05 \\
\hline lv6 (ac) & 14 & 6 & $28-36$ & $32-37$ & 33 & 33 & 2 & 2 & 0.07 & 0.05 \\
\hline lv7 (ac) & 14 & 6 & $27-37$ & $31-37$ & 33 & 35 & 3 & 2 & 0.08 & 0.06 \\
\hline la8 (tu) & 14 & 5 & $10-17$ & $11-16$ & 13 & 13 & 3 & 2 & 0.19 & 0.15 \\
\hline lv8 (ac) & 14 & 6 & $27-41$ & $36-40$ & 37 & 38 & 4 & 1 & 0.10 & 0.04 \\
\hline lv9 (ac) & 14 & 6 & $29-38$ & $25-34$ & 34 & 30 & 3 & 3 & 0.08 & 0.10 \\
\hline lv10 (f: ac, m: cr) & 14 & 6 & $19-31$ & $17-27$ & 26 & 24 & 3 & 4 & 0.11 & 0.17 \\
\hline lts & 14 & 6 & $85-102$ & $80-94$ & 93 & 87 & 5 & 6 & 0.05 & 0.07 \\
\hline ltas & 14 & 6 & $61-83$ & $63-72$ & 71 & 67 & 5 & 4 & 0.07 & 0.06 \\
\hline
\end{tabular}




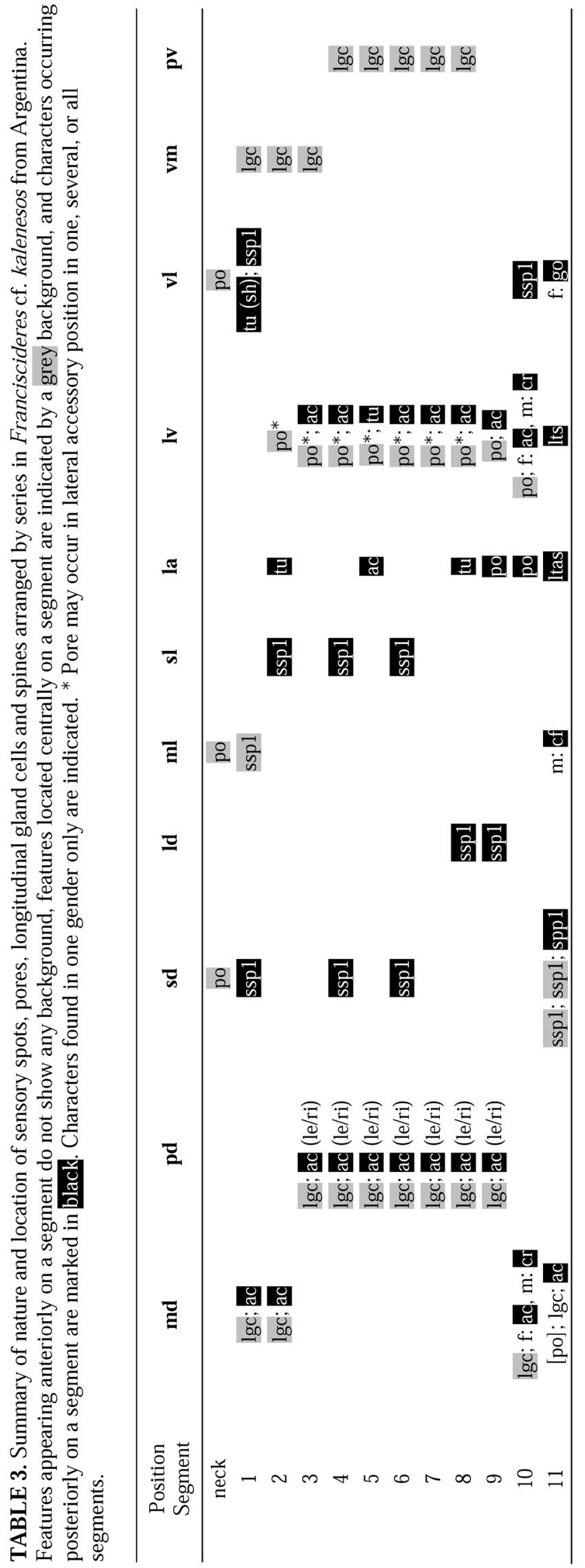


Neck. The neck is well developed, however, differentiated placids are absent. It appears as a flexible segmentlike ring, separated from segment 1 by a deep transverse fold. The neck cuticle is ornamented regularly with longitudinal elevations and depressions (crimps; Figs 4E, 5A, 9B). Pores are present centrally in subdorsal, midlateral and ventrolateral positions (Figs 6A, 9B; Table 3).

Trunk. Franciscideres cf. kalenesos is characterized by a slender and flexible trunk, with a very thin, soft and transparent cuticle (Figs 2, 4A, 8A; Table 2). Pachycycli are absent; any other kind of cuticular thickening is not apparent, except from the attachment points of some spines. All segments exhibit an almost circular cross-section. The trunk consists of 11 segments. Segments appear to be formed by a closed cuticular ring. Regularly arranged scale-like cuticular hairs cover the entire trunk, except for the secondary fringe. Each hair originates posteriorly from an anterior elongate scale-like ornamentation and may sometimes appear coiled up (Fig. 9E). Among these scale-like hairs occur scales, which are arranged irregularly in each segment and appear stronger sclerotized than the remaining hairs (Fig. 6A-E). At the anterior margin of segments 2-11 there is a secondary fringe consisting of knob-like structures, sometimes partially hidden under the free flap of the previous segment (Fig. 9E). The free flap of segments 1-9 is partly reduced and consists only of a series of pectinated lobes (Figs 2, 5B,C, 6A-E, 9C-F). The teeth of the pectinated lobes represent the primary pectinated fringe, which is found in segment 10.
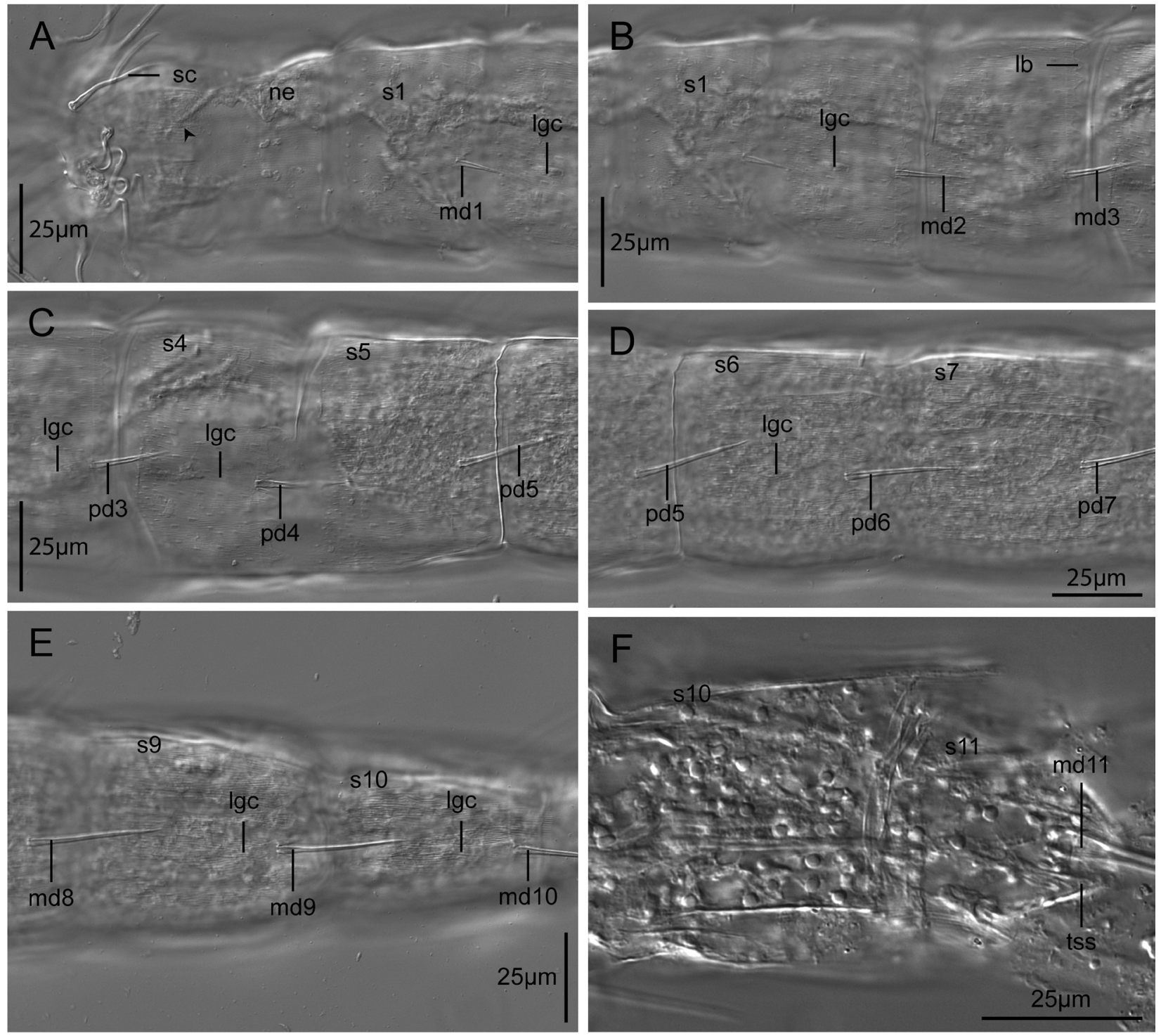

FIGURE 5. Light micrographs showing distribution of dorsal trunk structures of Franciscideres cf. kalenesos. Female ZMB 12148 (A-E) and ZMB 12145 (F). A. Head, neck and segment 1. B. Segments 1-3. C. Segments 4 and 5. D. Segment 6 and 7. E. Segments 9 and 10. F. Segments 10 and 11. Arrowheads in A mark the position of a cuticular field of short hairs posterior of the posteriormost ring of spinoscalids. 
The trunk is equipped with acicular spines and tubes. The former are thin and covered with tiny hairs throughout their length. The tubes are shorter and have a broad smooth proximal section separated from the distal narrow section, ornamented with longitudinal elevations and a transversal ring-like wrinkle (Fig. 9E). Both types of appendages insert in a notch of the free flap on the posterior segment margin, spines in dorsal or lateral position and tubes only in lateral position. Other structures observed are pores, which are single openings delimited by a more strongly sclerotized edge, potentially with secretory or sensory function, type-1 sensory spots, which are oval areas with micropapillae (Fig. 9C) and sometimes with long subcuticular canals through the trunk cuticle, and longitudinal gland cells (Fig. 5B-E, 6C-E). The latter are dorsal and ventral very elongate, narrow, subcuticular structures, some filled with a granular material and in other cases appearing just empty (Figs 5A-E, 6C-E). The dorsal structures seem to end at the dorsal spines, which may support a glandular function.

Segment 1 (Figs 2, 4E, 5A,B, 6A,B, 9C) with a middorsal spine and a pair of ventrolateral tubes. Tubes very short and inconspicuous, difficult to see especially in light microscopy (Figs 6A, 9C). Sensory spots present centrally in midlateral and posteriorly in subdorsal and ventrolateral positions. Longitudinal gland cells occurring in middorsal and ventromedial positions.
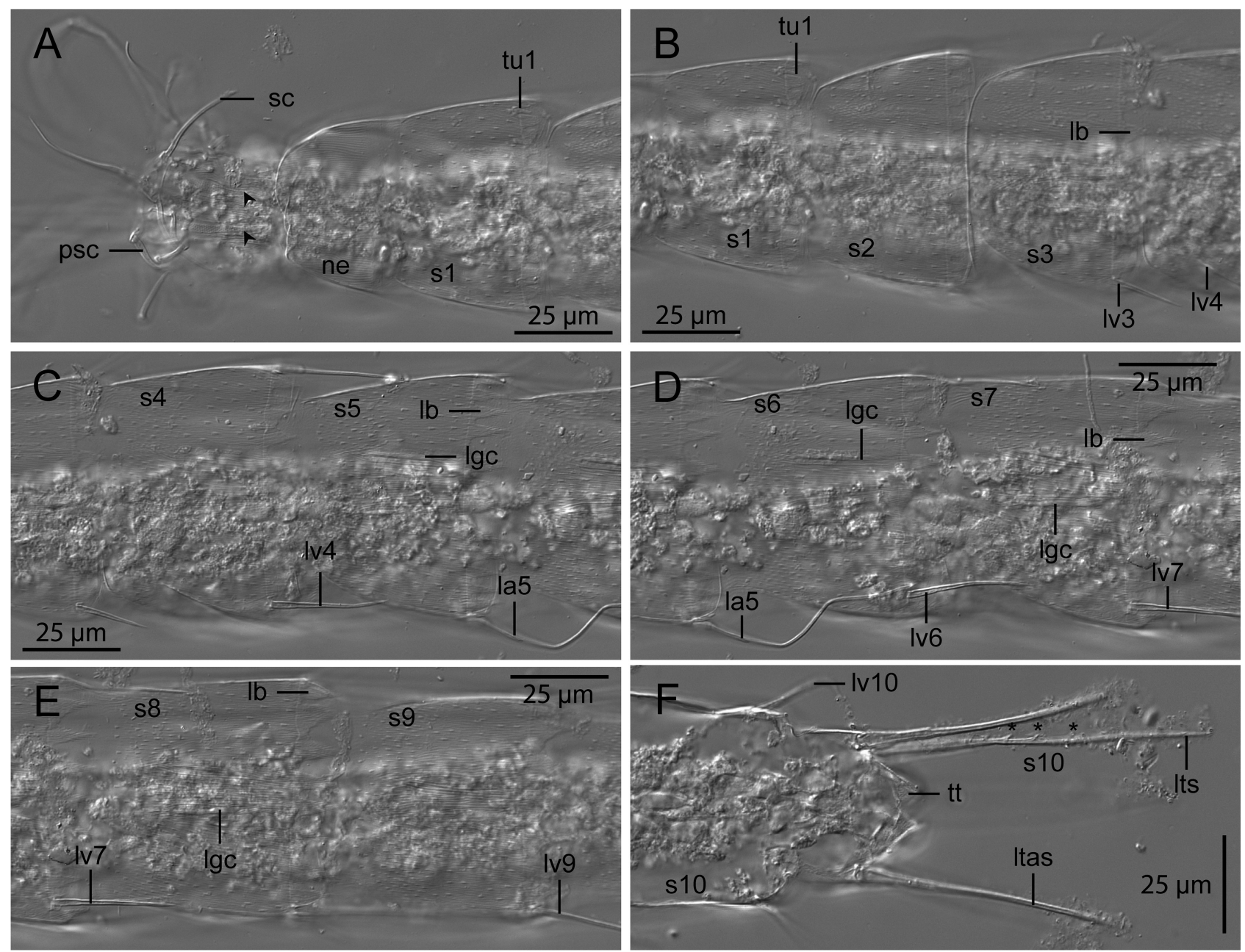

FIGURE 6. Light micrographs showing the distribution of ventral trunk structures of Franciscideres cf. kalenesos. Female ZMB 14127. A. Head, neck and segment 1. B. Segments 1 to 3. C. Segments 4 and 5. D. Segment 6 and 7. E. Segments 9 and 10. F. Segments 10 and 11. Arrowheads in $\mathbf{A}$ mark the position of cuticular fields of short hairs posterior of the posteriormost ring of spinoscalids. Asterisks mark thorn-like processes of lateral terminal spines.

Segment 2 (Figs 2, 5A,B, 6B) with a middorsal spine and a pair of lateral accessory tubes. Pores present centrally in lateroventral positions. Sensory spots located in the posterior part of the segment in sublateral positions. Longitudinal gland cells occurring in middorsal and ventromedial positions.

Segment 3 (Figs 2, 5B,C, 6B,C) with a paradorsal and a pair of lateroventral spines. Pores present centrally in lateroventral positions. Longitudinal gland cells occurring in paradorsal and ventromedial positions. 

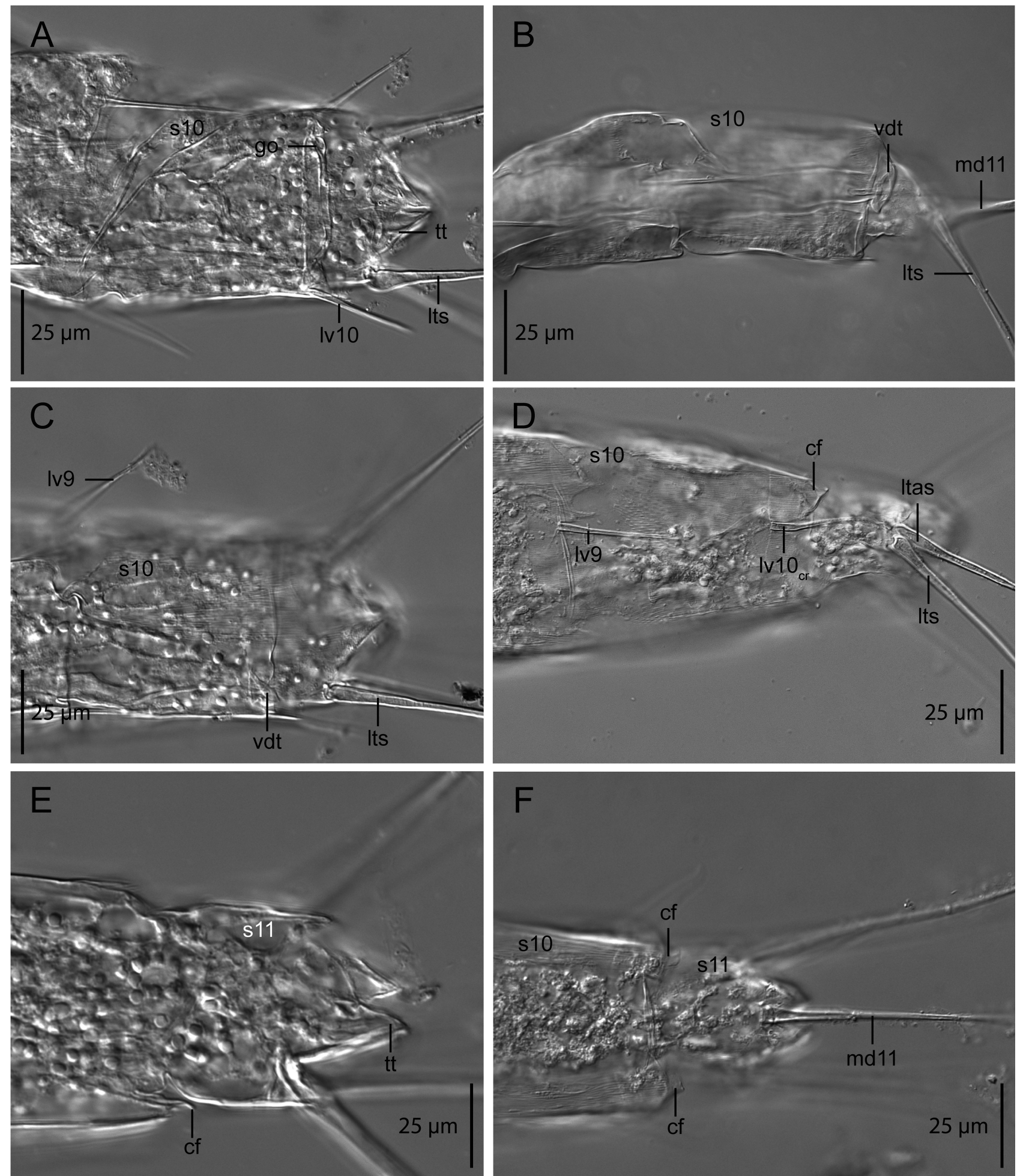

FIGURE 7. Light micrographs showing sexual dimorphism of Franciscideres cf. kalenesos on segment 10 and 11 . Female $(\mathbf{A}-\mathbf{C})$ and male (D-F), in ventral $(\mathbf{A}, \mathbf{C}, \mathbf{E})$ dorsal $(\mathbf{F})$ and lateral view $(\mathbf{B}, \mathbf{D})$. A. Gonopore on posterior margin of segment 10 [ZMB 12139]. B, C. Female-specific tubular structure [ZMB 11977, 12143]. D. Lateroventral crenulate spine [ZMB 11979]. E, F. Male-specific cuticular flap [ZMB 12137, 12127]. 


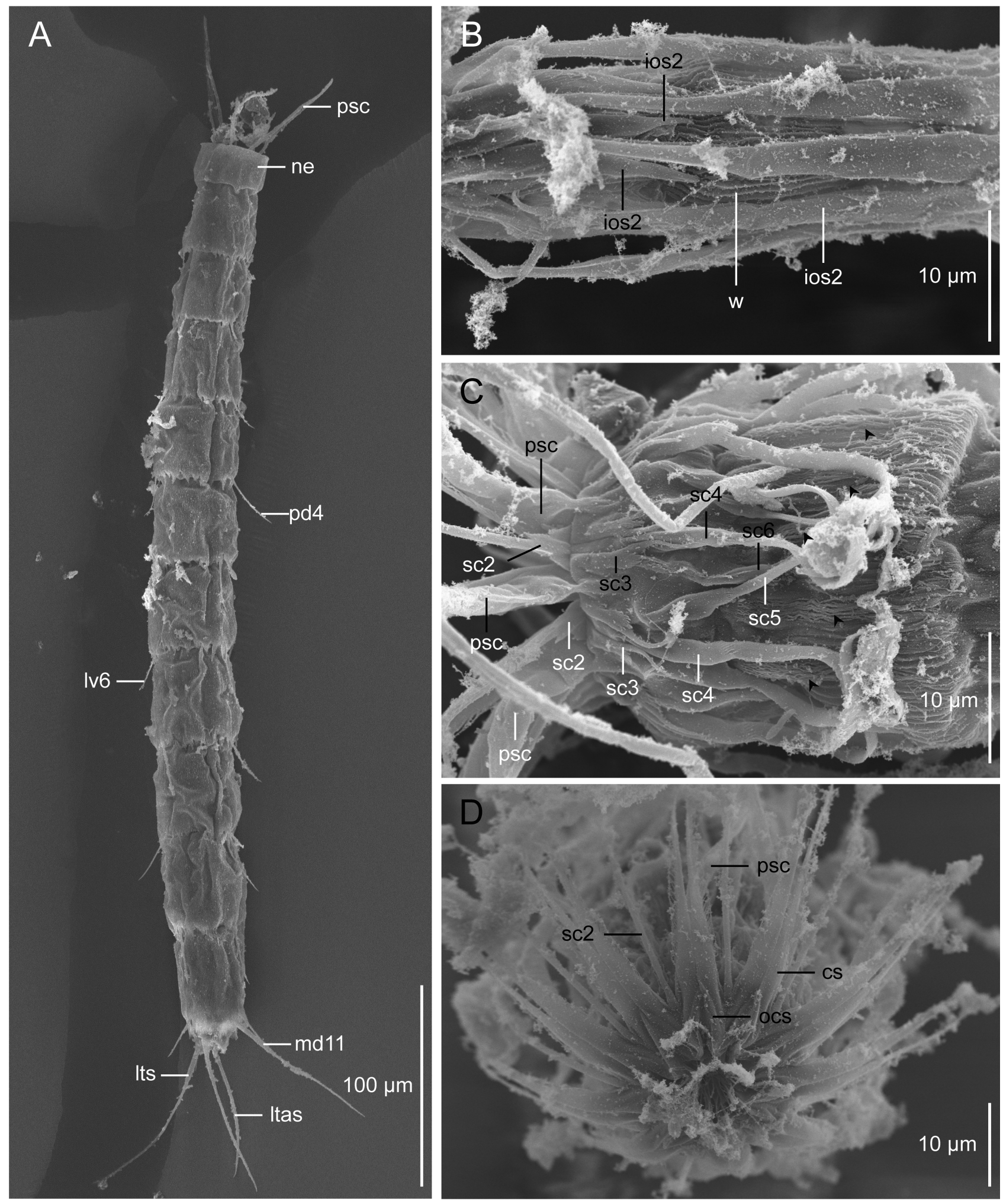

FIGURE 8. Scanning electron micrographs showing habitus and detailed morphology of the head of Franciscideres cf. kalenesos. Female (A, D), adult (B) and male $(\mathbf{C})$, in lateral $(\mathbf{A}, \mathbf{C})$, ventral $(\mathbf{B})$ and frontal view $(\mathbf{D})$. A. Overview of adult specimen [ZMB 12166]. B. Detail of mouth cone [ZMB 12154]. C, D. Detail of introvert [ZMB 12182, 12156]. Different colour lettering in $\mathbf{C}$ indicates scalids of neighbouring sectors. Arrowheads mark the cuticular fields of short hairs posterior of the posteriormost ring of spinoscalids. 

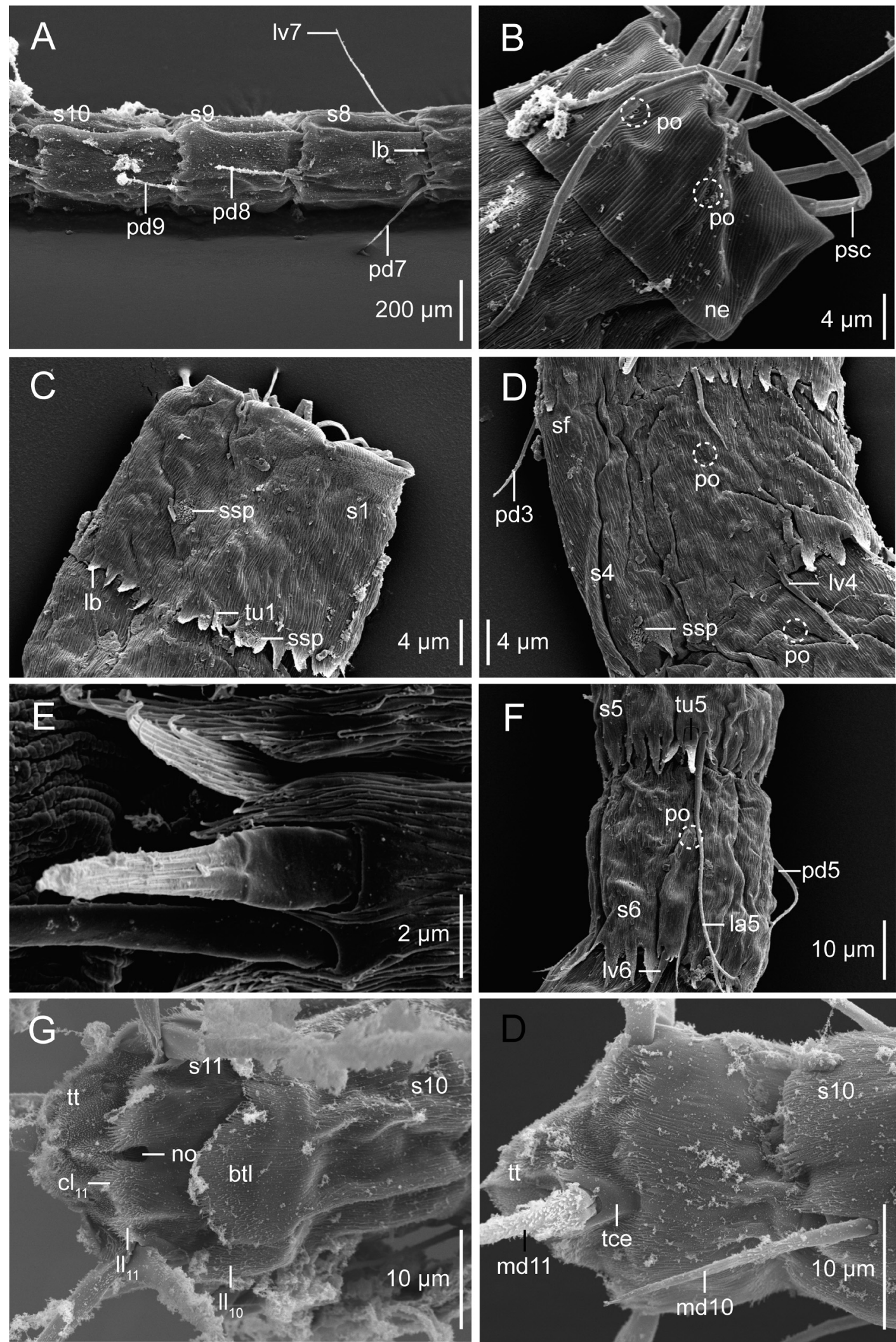

FIGURE 9. Scanning electron micrographs showing detailed trunk morphology of Franciscideres cf. kalenesos. Female (A), adult $(\mathbf{B}-\mathbf{F})$ and male $(\mathbf{G}, \mathbf{H})$, in dorsal $(\mathbf{A}, \mathbf{H})$ and lateral $(\mathbf{B}-\mathbf{F})$ view. A. Position of dorsal spines on segments 8 to 10 [ZMB 12151]. B. Neck and anterior part of segment 1 [MACN-In 43239d]. C. Detail of segment 1 [MACN-In 43239c]. D. Detail of segment 4 [MACN-In 43239c]. E. Detail of partly collapsed lateroventral tube of segment 2 [MACN-In 43239c]. F. Detail of segments 5 and 6 [MACN-In 43239c]. G. Posterior margin of segments 10 and 11 [ZMB 12172]. H. Detail of segment 11 [ZMB 12182]. 

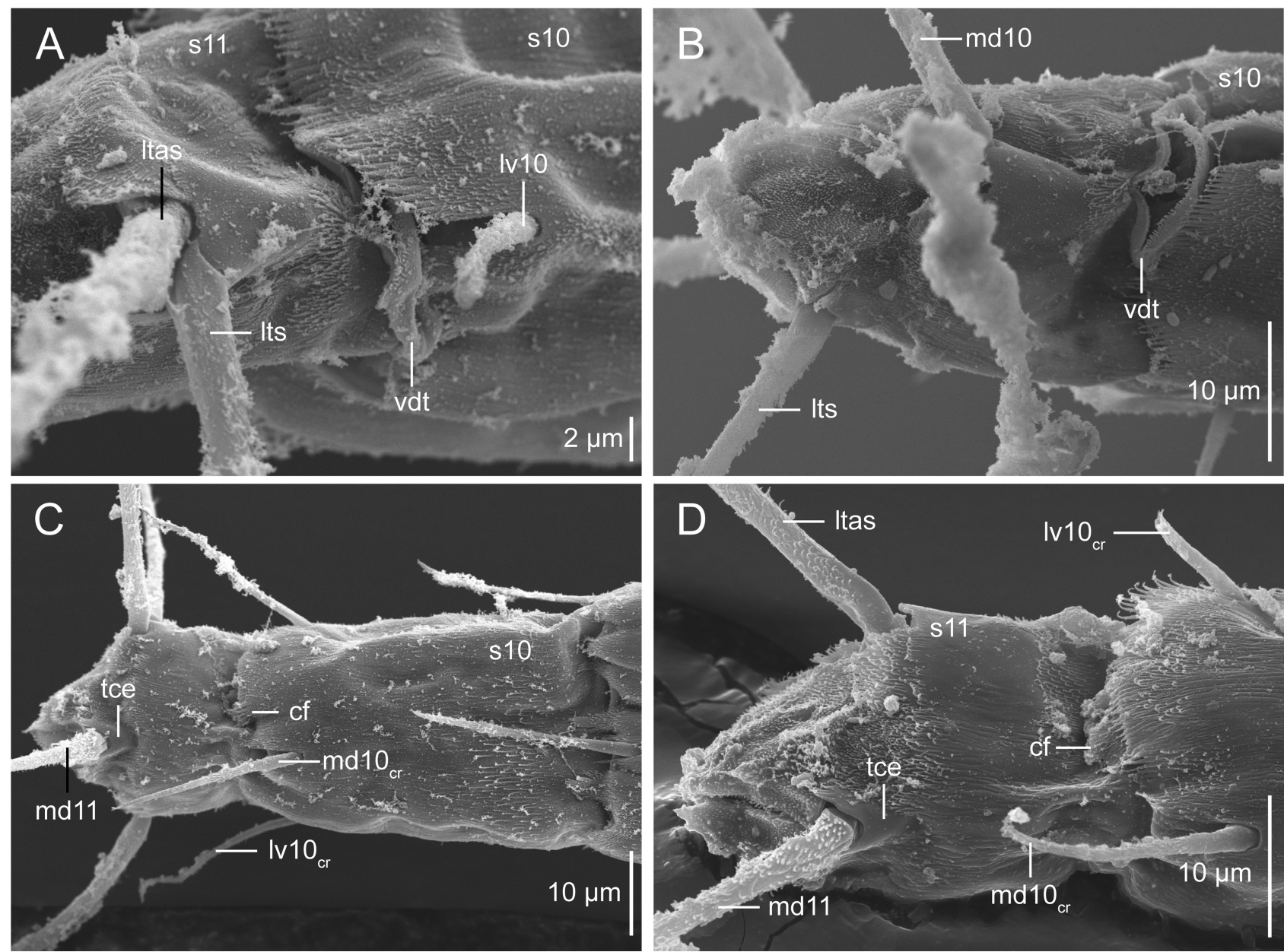

FIGURE 10. Scanning electron micrographs showing sexual dimorphism of Franciscideres cf. kalenesos on segment 10 and 11. A-B. Female, lateral view [ZMB 12181, 12175]. C-D. Male, ventral view [ZMB 12182, 12164].

Segment 4 (Figs 2, 5C, 6B,C, 9D) with a paradorsal and a pair of lateroventral spines. Pores occurring centrally in lateroventral positions. Sensory spots present posteriorly in subdorsal and sublateral positions. Longitudinal gland cells occurring in paradorsal and paraventral positions.

Segment 5 (Figs 2, 5C,D, 6C,D, 9E,F) with a paradorsal spine and a pair of lateroventral tubes and lateral accessory spines. Pores present centrally in lateroventral positions. Longitudinal gland cells occurring in paradorsal and paraventral positions.

Segment 6 (Figs 2, 5D, 6D, 9F) with a paradorsal and a pair of lateroventral spines. Pores present centrally in lateroventral positions. Sensory spots present close to the posterior segment margin in subdorsal and sublateral positions. Longitudinal gland cells occurring in paradorsal and paraventral positions.

Segment 7 (Figs 2, 5D, 6D,E) with paradorsal and a pair of lateroventral spines. Pores present centrally in lateroventral positions. Longitudinal gland cells occurring in paradorsal and paraventral positions.

Segment 8 (Figs 2, 5E, 6E) with a paradorsal spine and a pair of lateral accessory tubes and lateroventral spines. Pores present centrally in lateroventral positions. Sensory spots present near the posterior segment margin in laterodorsal positions. Longitudinal gland cells occurring in paradorsal and paraventral positions.

Segment 9 (Figs 2, 5E, 6E) with a paradorsal and a pair of lateroventral spines. Pores present posteriorly in lateral accessory and centrally in lateroventral positions. Sensory spots present posteriorly in laterodorsal positions. Longitudinal gland cells occurring only in paradorsal positions.

Segment 10 (Figs 2, 5E,F, 6F, 7, 9G,H, 10) with a middorsal and a pair of lateroventral spines. In females, spines being acicular and straight (Figs 2,7A, 10A), whereas in males being crenulated in their terminal two thirds of length (Figs 2, 7D, 10C,D). Segment extending ventrally in two lateral lobes and one central broad triangular 
lobe (Fig. 9G). Pores located posteriorly in lateral accessory and centrally in lateroventral positions. A pair of large sensory spots present posteriorly in ventrolateral positions. These structures being large oval fields of micropapillae, sometimes with one cilium emerging anteriorly. Longitudinal gland cells occurring middorsally anterior of spine. Free flap without pectinated lobes as the previous segments but with a pectinate fringe (Figs 2, 7E, 10).

Segment 11 (Figs 2, 5F, 6F, 7, 9G,H, 10) covered by hairs not arranged in any clear pattern, different from those present on the remaining segments (Fig. 9G, 10B). With a middorsal spine and a pair of lateral terminal and lateral terminal accessory spines. Spines covered basally by small hairs, and cuticle sclerotized at its attachment point. Lateral terminal spines being longer and carrying scattered thorn-like lateral processes (Fig. 6F). Free flap split ventrally into four lobes, two central lobes separated by an indentation and two lateral additional ones (Fig. 9G). Elevation of the cuticle anterior of and beside middorsal spine appearing as two wing-like structures ending in five processes (Figs 9H, 10C,D). Pore occurring anteriorly in middorsal position in few specimens. Sensory spots located in subdorsal positions, two centrally and one posteriorly, on each side. Longitudinal gland cells occurring middorsally anterior of spine. Segment extending as two triangular terminal extensions (Figs 2A,C, 9G,H). In addition, midlateral cuticular flaps, with an internal cavity, present only in males, partially covered by the free flap of segment 10 (Figs 7E,F, 10C,D). Females with hollow tubular structure expanding from ventrolateral to sublateral position connected probably with a ventrolateral gonopore (Figs 7A-C, 10A,B).

Variation of characters. The spine pattern is uniform in all the studied specimens. The very short ventrolateral tube of segment 1 could not be traced in several specimens. One specimen lacked the lateral accessory tube on segment 8 (ZMB 12183). Most of the detected variation in spines is related to the length of acicular spines of segment 5 (Table 2). In one specimen (MACN-In 43239c), segment 9 possessed two pores in lateral accessory position instead of a single pore as the remaining specimens. Additionally, two specimens showed two lateral accessory pores behind each other on segments 4 (ZMB 12175) or on segments 6, 7 and 9 (ZMB 12159). Lateral pores in segments 3-10 occurred in lateral accessory instead of lateroventral position in one or several segments of at least 10 specimens. Two additional specimens showed a lateral accessory sensory spot sublaterally on segment 5 (ZMB 12181) or with long subcuticular tubes on the right side of segment 3 (ZMB 12128).

Movements. Living specimens of Franciscideres cf. kalenesos from Argentina display different kinds of movements. The anterior segments are directly associated to the exploration activities in all three dimensions, displaying a wide range of elongation and retraction movements, while the posterior end seems to act as a kind of counter bearing remaining more or less stationary for some time (additional files 1 and 2). The animal can bend its body considerably, so the anterior end may reach behind the posterior end of the trunk. The scalids are not totally withdrawn into the trunk. Acicular spines are kept spread from the trunk most of the time. This set of activities reminds very much of similar activities of marine annelids.

Forward movement is achieved by frequent protrusion and withdrawal of the head and stretching of the anterior segments (additional file 3). At the same time, the long spines of segment 11 are used as counter bearing and spread as much as possible. Subsequently, the anterior segments until about segment 5 'anchor' to the substrate by spreading their acicular spines, and the posterior segments are drawn anteriorly by contraction of the segments.

The mouth cone appears quite robust and may reach the length of at least one segment, if fully protruded (additional file 3). While the mouth cone is protruded, the outer oral styles are moved outwards beyond the diameter of the mouth cone and subsequently towards the centre again in a kind of grasping movement. This grasping can continue a couple of times while the mouth cone is still protruded. Protrusion of the mouth cone may be just partial, and it may happen extremely fast. The cone may remain protruded for some time.

\section{Discussion}

The family Franciscideridae was recently established based on molecular and morphological data (Sørensen et al. 2015). This group is composed solely of two monotypical genera, Franciscideres (with F. kalenesos from Brazil) and Gracilideres (with G. mawatarii from Japan). These species share an unusual combination of morphological characters not found in many other kinorhynchs, i.e. trunk slender with thin and extremely flexible cuticle, neck cylindrical, without differentiated placids, small pores present at least on trunk segments, segment 11 with middorsal, lateral terminal, and lateral terminal accessory spines, but without midterminal spine (Dal Zotto et al. 2013; Yamasaki 2019). 
Specimens collected in Argentina resemble Franciscideres kalenesos, but due to the presence of some different characters we are unable to ensure that these two morphotypes represent the same species. Therefore, we consider our exemplars as Franciscideres cf. kalenesos until new data from the Brazilian population will become available.

\section{Morphological comparison with Franciscideres kalenesos from Brazil}

Franciscideres kalenesos was originally described on the basis of the holotype (gender uncertain) mounted in glycerine, five paratypes (some of them possibly pre-adults, but at least one adult) mounted together on a SEM stub, and some additional material from the type locality, but not in the type series: two specimens used for molecular sequencing, two specimens mounted for SEM. Other specimens from Guaratuba were in a very bad condition, and a single specimen from Boissucanga beach was studied and photographed alive, but subsequently lost (Dal Zotto et al. 2013). In 2019, new specimens were collected from Guaratuba and Santa Catarina, however, these were used exclusively for autecological studies (Lopes Mello et al. 2019). Therefore, some morphological details were only reported for the type locality specimens and nothing is known about the potential variability of this species.

Our material from Argentina agreed with Franciscideres kalenesos from Brazil in general morphology. Several other characters observed in the Argentinian specimens were not described for the Brazilian material, but we cannot rule out that they are present also in these populations, viz, (1) presence of ventrolateral tubes on segment 1, (2) introvert features, (3) each segment composed of a closed cuticular ring, (4) trunk cuticle ornamented by a secondary fringe of knob-like structures, (5) ventral free flap of segment 10 terminating in two lateral and one broad triangular lobes, (6) ventral free flap of segment 11 centrally terminating in four lobes, (7) lateral terminal spines armed with thorn-like processes, (8) pores/sensory spots/glands distribution and (9) sexual dimorphism in segments 10 and 11 (Tables 4, 5). In addition, some of the differences noted (Tables 4, 5) are probably compatible with the amount of species-specific variation now recognized in other Kinorhyncha species (Neuhaus \& Sørensen 2013; Neuhaus et al. 2014, 2019; Neuhaus \& Kegel 2015; Sánchez et al. 2019; Yamasaki \& Dal Zotto 2019).

Introvert morphology. The introvert of both populations of Franciscideres might not be so different. Franciscideres kalenesos from Brazil seemed to be equipped with at least four rings of scalids, whereas $F$. cf. kalenesos from Argentina has six rings. Further comparison regarding the number of scalids cannot be accomplished because of the poor information available from the Brazilian population.

Anteriorly of the primary spinoscalids of the Argentinian specimens, a ring of 20 thin cuticular spinose processes was discernible under LM and SEM microscopy. Dal Zotto et al. (2013) observed that primary spinoscalids were distally bifurcated due to the presence of a cleft. However, what they named 'cleft' were in fact the cuticular spinose processes anterior of the primary spinoscalids observed in Franciscideres cf. kalenesos from Argentina. In Dal Zotto et al.'s Fig. 5 one does not see these cuticular spinose processes as in the Argentinean specimens, because in their specimens the mouth cone and foregut were artificially protruded forcing the spinose processes on top of the primary spinoscalids. Amazingly, such spinose processes were also reported for Cateria gerlachi and C. styx (see Neuhaus \& Kegel 2015; Herranz et al. 2019).

Regarding the primary spinoscalids, our exemplars presented annulated primary spinoscalids, which were not described for Franciscideres kalenesos from Brazil but visible in the SEM photos (Dal Zotto et al. 2013, fig. 7).

In Franciscideres cf. kalenesos, 14 fields of cuticular hairs appeared posterior of the spinoscalids. These areas were not observed by Dal Zotto et al. (2013) for F. kalenesos from Brazil but their presence was confirmed by Yamasaki (2019) based on personal unpublished observation by Dal Zotto.

Trunk cuticular plate composition. The cuticular plates of segments seemed to differ in both populations. Segments 1, 2 and 11 appeared as closed rings and segments 3 to 10 'sometimes' with a weak indication of a midsternal junction in Franciscideres kalenesos from Brazil (Dal Zotto et al. 2013, p. 307). In the Argentinean specimens, each segment appeared to be formed by a single closed cuticular ring, a midsternal junction was not discernible in any specimen. This situation calls for a re-investigation of the known and of new material from Brazil.

Trunk cuticular structures. The spine formula of Franciscideres $\mathrm{cf}$. kalenesos from Argentina differed slightly from that of the Brazilian species (Table 5). The main difference was due to the presence of a pair of ventrolateral tubes on segment 1 in the Argentinean species, whereas these tubes were not observed in F. kalenesos from Brazil. These tubes were very short and hard to see under light microscopy, and possibly this structure was overlooked in the Brazilian species. The remaining spines were in the same position as the Brazilian specimens, with two exceptions: lateroventral tubes on segment 2 were displaced to lateral accessory positions and middorsal spines from 
segment 3 to 9 were displaced to a paradorsal position. Our interpretation of the published images of F. kalenesos from Brazil (Dal Zotto et al. 2013, fig. 17) suggests that the lateral spine on segment 2 is in this species actually in a lateral accessory position rather than a lateroventral position. Franciscideres kalenesos from Brazil possessed also paradorsally displaced spines, however, it is unknown if these spines were the same as in the Argentinean population (Herranz et al. 2019).

TABLE 4. Comparison of selected characters of Franciscideres cf. kalenesos from Argentina and F. kalenesos from Brazil.

\begin{tabular}{|c|c|}
\hline $\begin{array}{l}\text { Franciscideres cf. kalenesos from Argentina } \\
\text { (this study) }\end{array}$ & $\begin{array}{l}\text { Franciscideres kalenesos from Brazil } \\
\text { (after Dal Zotto et al. 2013) }\end{array}$ \\
\hline at least two rings of inner oral styles & inner oral styles not observed \\
\hline nine outer oral styles rigid and formed by three elements & $\begin{array}{l}\text { outer oral styles not seen in SEM specimens but visible } \\
\text { inside the trunk of specimens with retracted head (Dal } \\
\text { Zotto et al. 2013, fig. 16) }\end{array}$ \\
\hline probably six rings of scalids in the introvert & relatively few rings, perhaps around four \\
\hline $\begin{array}{l}10 \text { pairs of cuticular spinose processes anterior of primary } \\
\text { spinoscalids }\end{array}$ & $\begin{array}{l}10 \text { pairs of cuticular spinose processes anterior of } \\
\text { primary spinoscalids, corresponding to "ring } 01 \text { " of Dal } \\
\text { Zotto et al. (2013) }\end{array}$ \\
\hline apically annulated primary spinoscalids & $\begin{array}{l}\text { not described, but visible in SEM photos (Dal Zotto et } \\
\text { al. 2013, fig. 7) }\end{array}$ \\
\hline ring 02 of introvert with 10 long spinoscalids with basal sheath & $\begin{array}{l}\text { ring } 02 \text { with ten thin scalids, possibly gap between rings } \\
02 \text { and } 03\end{array}$ \\
\hline ring 03 with 20 very short scalids with basal sheath & $\begin{array}{l}\text { ring } 03 \text { with ten scalids radially aligned with those in } \\
\text { ring } 02\end{array}$ \\
\hline ring 04 with ten scalids with basal sheath & absent \\
\hline $\begin{array}{l}\text { all trunk segments formed by closed cuticular rings; a midster- } \\
\text { nal junction not discernible }\end{array}$ & $\begin{array}{l}\text { segments } 1,2 \text { and } 11 \text { closed rings; segments } 3-10 \text { some- } \\
\text { times with a weak indication of a midsternal junction }\end{array}$ \\
\hline $\begin{array}{l}\text { trunk cuticle ornamented with a secondary fringe of knob-like } \\
\text { structures }\end{array}$ & secondary fringe not described \\
\hline dorsal spines of segments $3-9$ displaced to paradorsal positions & at least some dorsal spines displaced paradorsally \\
\hline ventral free flap of segment 10 terminating in two lateral lobes & free flap of segment 10 not lobed midventrally but with \\
\hline and one broad midventral triangular lobe & straight border \\
\hline ventral free flap of segment 11 with midventral notch & ventral free flap of segment 10 straight \\
\hline lateral terminal spines armed with thorn-like processes & lateral terminal spines ornamented with 'tiny hairs' \\
\hline sexual dimorphism: female with acicular spines on segment 10 & no characters to distinguish the sexes observed \\
\hline \multicolumn{2}{|l|}{ and male with crenulated spines; male with midlateral cuticular } \\
\hline \multicolumn{2}{|l|}{ flap with cavity anteriorly on segment 11 ; female with hollow } \\
\hline \multicolumn{2}{|l|}{ tubular structure expanding from ventrolateral to sublateral } \\
\hline \multicolumn{2}{|l|}{ position connected probably with a ventrolateral gonopore } \\
\hline anteriorly on segment 11 & \\
\hline
\end{tabular}

The Argentinean exemplars displayed a secondary fringe with a knob-like ornamentation, whereas this character was not described for the Brazilian Franciscideres kalenesos, possibly because the free flap of the previous segment covered the area of the secondary fringe in the subsequent segment or because it was absent (Dal Zotto et al. 2013, fig. 8).

The pectinate fringe of the free flap of segment 10 of the Argentinean animals projected distally as two lateral and one midventral broad triangular lobes, whereas the pectinate fringe of the Brazilian exemplars was illustrated as a more or less distal straight line without any projecting lobe (Dal Zotto et al. 2013, p. 312, fig. 2). A similar situation appeared on segment 11, where in Franciscideres kalenesos from Brazil the posterior margin appeared more or less straight, whereas in the Argentinean population it split into four ventral lobes. 


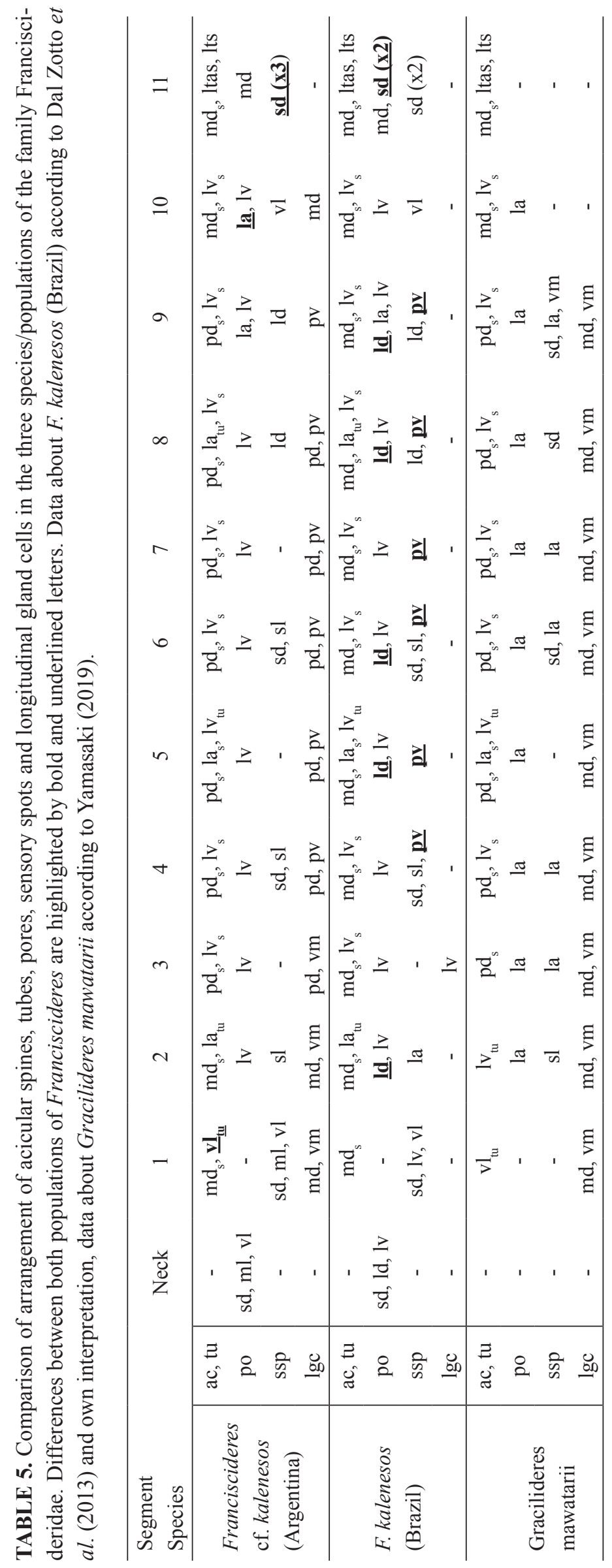


Evident in our specimen was the presence of thorn-like processes on the lateroterminal spines. In Franciscideres kalenesos from Brazil, 'minute hairs' were recognizable instead of well-developed thorns (Dal Zotto et al. 2013, fig. 22). However, this impression may depend on the orientation of the spine to the observer.

Pores, sensory spots and longitudinal gland cells. Both populations of Franciscideres differed in the distributions of pores, sensory spots and gland cells (Table 5). Longitudinal gland cells were not reported for the Brazilian specimens, but one gland is recognizable in one published image, viz, lateroventrally on segment 3 just anterior of the spine (Dal Zotto et al. 2013, fig. 17; Table 5). This finding indicates that longitudinal gland cells may occur also in other segments and positions of the Brazilian population. Pores on the neck in laterodorsal and lateroventral appeared in a midlateral and ventrolateral position, respectively, but this may depend a bit on the interpretation of positions by different persons. Laterodorsal pores on segments 2, 5, 6, 8, and 9 and paraventral sensory spots on segments 4-9 present in Franciscideres kalenesos from Brazil were not observed in the Argentinean population (Table 5). Besides, an additional sensory spot was present subdorsally on segment 11 in the Argentinean specimens (Table 5).

Sexual dimorphism. The specimens of Franciscideres cf. kalenesos from Argentina revealed sex-specific differences. Females possessed acicular spines middorsally and lateroventrally on segment 10, whereas males had crenulated spines on this segment. Females possessed on segment 11 tubular structures expanding from a ventrolateral to a sublateral position, whereas males had midlateral cuticular flaps. It is necessary to check, if all these structures are present also in specimens from Brazil.

The diagnostic characters of Franciscideres cf. kalenesos from Argentina agreed with the original description based on the Brazilian exemplars. The observed morphological differences of the animals collected in Argentina are interpreted as morphological variation or may have been overlooked in the Brazilian specimens. Recent articles found that intraspecific variation may be considerably larger in Kinorhyncha than previously assumed and our results seem to support these observations (Neuhaus \& Sørensen 2013; Neuhaus et al. 2014, 2019; Neuhaus \& Kegel 2015; Sánchez et al. 2019; Yamasaki \& Dal Zotto 2019).

\section{Comparative morphological notes about Gracilideres mawatarii from Japan}

Yamasaki (2019) provided a comparison between Franciscideres kalenesos from Brazil and Gracilideres mawatarii. We supply some new morphological data of the genus Franciscideres based on the Argentinean specimens.

Introvert. The introvert of Franciscideres cf. kalenesos from Argentina and probably also of $F$. kalenesos from Brazil was equipped with ten pairs of spinose cuticular processes anterior of the primary spinoscalids. Yamasaki (2019) reported the presence of a cleft at the base of the primary spinoscalids, which divided them into a distal bifurcation. This last situation is similar to that reported by Dal Zotto et al. (2013). We interpret the bifurcated structures as the anterior cuticular processes of the primary spinoscalids as seen in our specimens of Franciscideres $\mathrm{cf}$. kalenesos, Cateria gerlachi and C. styx (comp. Dal Zotto et al. 2013, fig. 5; Neuhaus \& Kegel 2015, fig. 26F; Dal Zotto \& Yamasaki 2019, fig. 2C).

Trunk cuticular structures. Franciscideres cf. kalenesos and Gracilideres mawatarii shared the cuticular plate composition. In both species, segments 1-11 were composed of closed rings, different from Franciscideres kalenesos from Brazil; however, the latter needs to be reexamined to confirm the actual trunk composition of this species (Yamasaki 2019).

Both genera differed in the shape of the posterior edge of each trunk segment. In Gracilideres mawatarii the free flap of the trunk segments 1-10 terminated into primary pectinate fringes, while in both populations of Franciscideres kalenesos the free flap was reduced to a number of pectinated lobes (Dal Zotto et al. 2013; Yamasaki 2019; this paper).

Spines of segments 3-9 of Gracilideres mawatarii were located paradorsally, while those of segment 10 and 11 were middorsally. Dorsal spines of Franciscideres kalenesos from Brazil are slightly paradorsally displaced according to Herranz et al. (2019). Dorsal spines from segments 3-9 of the Argentinean population were also displaced to a paradorsal position, similar to the situation reported for G. mawatarii. This condition of paradorsally displaced middorsal spines is present in species of the genera Dracoderes, Cateria, and Tubulideres (see Higgins \& Shirayama 1998; Sørensen et al. 2007, 2012; Thomsen et al. 2013; Neuhaus 2017; Herranz et al. 2019). The phylogenetic interpretation of this feature requires further studies. 
Distinctive of Gracilideres mawatarii was the presence of what Yamasaki (2019) called string-like gland cells. Structures in a similar position are reported here for Franciscideres from Argentina, which we called longitudinal gland cells (Table 5). Gracilideres mawatarii was mounted and stored in Hoyer's mounting medium for years, which is known to dissolve internal organs in order to make cuticular features more clearly visible (Neuhaus et al. 2017). Therefore, no cellular structures remained in G. mawatarii except for some weak cuticular marks. This is opposite to our material, which was mounted in glycerol and allowed study of internal organs. Because of the similar position of the structures we suggest that the string-like structures of G. mawatarii are homologous to the longitudinal gland cells of Franciscideres $\mathrm{cf}$. kalenesos. These probably secretory structures were located in specific areas, dorsally anterior of dorsal spines (dorsally or paradorsally) and paired in ventral positions (ventromedially in Gracilideres and ventromedially or paraventrally in Franciscideres cf. kalenesos from Argentina). Their presence in Franciscideres from Brazil is known at least for segment 3 (Dal Zotto et al., 2013, fig. 17).

The current record of Franciscideres cf. kalenesos in Argentina represents the first study of this phylum in 15 years since Martorelli and Higgins (2004) and rises to six the number of recorded species. The fauna of these interstitial animals is underestimated and further studies are needed in order to explore the biodiversity of this neglected phylum in South American waters.

\section{Movement}

Comparison within Kinorhyncha. Strongly armoured species of Kinorhyncha perform their movement by continuously ejecting and retracting the introvert, anchoring the scalids in the sediment, and pulling the rest of the body forward (Neuhaus \& Higgins 2002; Neuhaus 2013; Herranz et al. 2014, additional file 3). Only about ten species in the genera Franciscideres, Cateria, Gracilideres, Triodontoderes, Tubulideres, and Zelinkaderes have a slender trunk with a thin and flexible body cuticle (Gerlach 1956; Higgins 1968, 1990; Bauer-Nebelsick 1995; Sørensen et al. 2007; Altenburger et al. 2015; Neuhaus \& Kegel 2015; Neuhaus 2017; Yamasaki 2019). Herranz et al. (2019) reported that Cateria styx from Brazil displayed an accordion-like movement, where the trunk seems to stretch and contract along its anterior-posterior axis combined with fast twisting and coiling of the trunk, giving the appearance of a worm rather than a kinorhynch. This annelid-like movement reported for Cateria and also seen in Cateria gerlachi from Sri Lanka (Neuhaus unpubl. obs.) was similar to what we observed for specimens of Franciscideres from Argentina. In addition, we noted that Franciscideres $\mathrm{cf}$. kalenesos used its spines as a counter bearing during forward movement (additional file 3). It can be predicted that also species of Gracilideres, Triodontoderes, Tubulideres, and Zelinkaderes will move in a similar way.

Neuhaus and Kegel (2015, p. 66) wrote: "An extremely protrusible mouth cone is reported for Cateria gerlachi, C. styx from Brazil and Angola, for Zelinkaderes yong, and possibly for Franciscideres kalenesos for which documentation is a bit sparse in this respect (Gerlach 1956, fig. 11; Delamare-Deboutteville 1957, fig. g; Dal Zotto et al. 2013, p. 311; Altenburger et al. 2015, fig. 4A, C; this article). The long mouth cone with its outer oral styles may function as a kind of forceps for selectively picking food particles. Observations concerning extreme protrusability of the mouth cone is quite poor for other kinorhynch species [...]". Our observations on live Franciscideres cf. kalenesos from Argentina (additional file 3) document that the mouth cone can be extremely protruded in $F$. kalenesos and that the outer oral styles make a grasping movement. These observations may support the above-mentioned hypothesis, but do not represent proof of it, because no food particles were involved in the activity observed.

Comparison with other meiofaunal groups. The oligochaete-like movement seen in Franciscideres is not common among the Kinorhyncha, which mostly have stronger and more rigid cuticles. However, a vermiform body plan is one of the most widespread convergent features of the meiofaunal organisms, which live and move through the interstices in between the sand grains (Rundell \& Leander 2010), and peristaltic locomotion has been acquired independently by tiny vermiform organisms of very different phyla. A noteworthy example is that of mites in the family Nematalycidae, which have a slender, vermiform body with a flexible cuticle that can extend and contract, much like that of an actual worm. They have only longitudinal muscles, but they crawl by peristaltic movements in which the contractible cuticle plays a fundamental role (Haupt \& Coineau 1999, Bolton et al. 2015). The study of the muscle specializations of Franciscideres and other genera with soft cuticles could give functional and evolutionary insights of the motion of these unusual Kinorhyncha. 


\section{Additional files}

Three additional videos show live specimens of Franciscideres cf. kalenesos and are available via the data publisher Museum für Naturkunde Berlin (MfN) - Leibniz Institute for Evolution and Biodiversity Science, https://doi. org/10.7479/8skj-tq91.

Additional file 1. Video showing movement of Franciscideres cf. kalenesos (Kinorhyncha) from Argentina on a microscope slide using its introvert and trunk (magnification 40x).

Additional file 2. Video showing movement of Franciscideres $\mathrm{cf}$. kalenesos (Kinorhyncha) from Argentina on a microscope slide, displaying dorsal, ventral and forward/backward movements (magnification 100x).

Additional file 3. Video showing the protrusion of the mouth cone of Franciscideres cf. kalenesos (Kinorhyncha) from Argentina and a grasping movement of the outer oral styles (magnification 100x).

\section{Acknowledgements}

This study was supported by Universidad Nacional del Sur (Grant for Graduated Students and PGI 24B/244). We would like to thank Lic. Agustín Menechella and Lic. Ana Paula Andrieu, IADO, CONICET, for their kind help in field collections. In addition, we greatly appreciate technical support at the SEM by Kirsten Born and Anke Sänger, Museum für Naturkunde Berlin.

\section{References}

Altenburger, A., Rho, H.S., Chang, C.Y. \& Sørensen, M.V. (2015) Zelinkaderes yong sp. nov. from Korea-the first recording of Zelinkaderes (Kinorhyncha: Cyclorhagida) in Asia. Zoological Studies, 54 (25), 1-13. https://doi.org/10.1186/s40555-014-0103-6

Bauer-Nebelsick, M. (1995) Zelinkaderes klepali sp. n., from shallow waters sands of the Red Sea (Kinorhyncha: Cyclorhagida: Zelinkaderidae). Annalen des Nathistorischen Museums Wien, 97B, 57-74.

Bolton, S.J., Bauchan, G.R., Ochoa, R., Pooley, C. \& Klompen, H. (2015) The role of the integument with respect to different modes of locomotion in the Nematalycidae (Endeostigmata). Experimental and Applied Acarology, 65 (2), $149-161$. https://doi.org/10.1007/s10493-014-9857-0

Caló, J.E., Fernández, E.M. \& Aldacour, H.E. (1995) Caracterización ambiental de la playa de Pehuen-Có en base a procesos oceanográficos y atmosféricos. Su importancia en el manejo costero. Jornadas de Geología y Medio Ambiente, Río Cuarto, 1995, Resúmenes, 223-236.

Caló, J.E., Fernández, E., Marcos, A. \& Aldacour, H. (2005) Observaciones litorales ambientales de olas, corrientes y vientos de la playa de Monte Hermoso entre 1996 y 1999. Geoacta, 30, 27-38.

Dal Zotto, M., Di Domenico, M., Garrafoni, A. \& Sørensen, M.V. (2013) Franciscideres gen. nov.—a new, highly aberrant kinorhynch genus from Brazil, with an analysis of its phylogenetic position. Systematics and Biodiversity, 11, $303-321$. https://doi.org/10.1080/14772000.2013.819045

Delamare-Deboutteville, C. (1957) Sur la présence des Echinodères de la famille des Cateriidae Gerlach dans les eaux souterraines littorales de l'Angola. Publiçacoes Culturais da Companhia de Diamantes de Angola, 34, 33-37.

Fiori, S. (2002) Ecología de las poblaciones de almeja amarilla (Mesodesma mactroides) en el extremo austral de distribución de la especie. PhD Thesis, Universidad Nacional del Sur, Bahía Blanca, 138 pp.

Gerlach, S.A. (1956) Über einen aberranten Vertreter der Kinorhynchen aus dem Küstengrundwasser. Kieler Meeresforschungen, $12(1), 120-124$.

Giere, O. (2009) Meiobenthology. The microscopic motile fauna of aquatic sediments. 2nd edition. Springer, Berlin, 527 pp.

Herranz, M., Di Domenico, M., Sørensen, M.V. \& Leander, B.S. (2019) The enigmatic kinorhynch Cateria styx Gerlach, 1956A sticky son of a beach. Zoologischer Anzeiger, 282, 10-30. https://doi.org/10.1016/j.jcz.2019.05.016

Higgins, R.P. (1968) Taxonomy and postembryonic development of the Cryptorhagae, a new suborder for the mesopsammic kinorhynch Cateria. Transactions of the American Microscopical Society, 87 (1), 21-39. https://doi.org/10.2307/3224334

Higgins, R.P. (1990) Zelinkaderidae, a new family of cyclorhagid Kinorhyncha. Smithsonian Contributions to Zoology, 500, $1-26$. https://doi.org/10.5479/si.00810282.500

Lang, K. (1949) Echinoderida. Further Zoological Results of the Swedish Antarctic Expedition 1901-1934, 1949, 1-22.

Lang, K. (1953) 9. Echinoderida. Reports of the Lund University Chile Expedition 1948-1949. Lunds Universitets Arsskrift, Neue Folge, Avd. 2, 49 (4), 3-8. 
Lopes Mello, C. (2017) Padrão de distribuição espacial do gênero aberrante Franciscideres (Kinorhyncha) em praias arenosas no sul do Brasil. Bachelor's degree in Oceanography Thesis, Federal University of Paraná, Pontal do Paraná, 35 pp.

Lopes Mello, C., Carvalho, A.L., Cabral de Faria, L., Baldoni, L. \& Di Domenico, M. (2019) Spatial distribution pattern of the aberrant Franciscideres kalenesos (Kinorhyncha) on sandy beaches of Southern Brazil. Zoologischer Anzeiger, 282, 44-51. https://doi.org/10.1016/j.jcz.2019.05.008

Martorelli, S. \& Higgins, R.P. (2004) Kinorhyncha from the stomach of the shrimp Pleoticus muelleri (Bate, 1888) from Comodoro Rivadavia, Argentina. Zoologischer Anzeiger, 243, 85-98. https://doi.org/10.1016/j.jcz.2004.07.003

Miloslavich, P., Klein, E., Díaz, J.M., Hernández, C.E., Bigatti, G., Campos, L., Artigas, F., Castillo, J., Penchaszadeh, P.E., Neill, P.E., Carranza, A., Retana, M.V., Díaz de Astarloa, J.M., Lewis, M., Yorio, P., Piriz, M.L., Rodríguez, D., YoneshigueValentin, Y., Gamboa, L. \& Martín, A. (2011) Marine biodiversity in the Atlantic and Pacific coasts of South America: knowledge and gaps. PloS ONE, 6 (1), e14631. https://doi.org/10.1371/journal.pone.0014631

Haupt, J. \& Coineau, Y. (1999) Ultrastructure and functional morphology of a nematalycid mite (Acari: Actinotrichida: Endostigmata: Nematalycidae): adaptations to mesopsammal life. Acta Zoologica, 80, 97-111. https://doi.org/10.1046/j.1463-6395.1999.80220002.x

Neuhaus, B. (2013) 5. Kinorhyncha (= Echinodera). In: Schmidt-Rhaesa, A. (Ed.), Handbook of Zoology. Gastrotricha, Cycloneuralia and Gnathifera. Vol. 1. Nematomorpha, Priapulida, Kinorhyncha, Loricifera. Walter de Gruyter, Berlin, pp. 181-348.

Neuhaus, B. (2017) Redescription of Tubulideres seminoli Sørensen et al., 2007 and notes on Wollunquaderes majkenae Sørensen and Thormar, 2010 (Kinorhyncha, Cyclorhagida): morphology, postembryonic, life cycle and new characters. Zoologischer Anzeiger, 270, 123-154. https://doi.org/10.1016/j.jcz.2017.09.004

Neuhaus, B. \& Higgins, R.P. (2002) Ultrastructure, biology, and phylogenetic relationships of Kinorhyncha. Integrative and Comparative Biology, 42 (3), 619-632. https://doi.org/10.1093/icb/42.3.619

Neuhaus, B. \& Kegel, A. (2015) Redescription of Cateria gerlachi (Kinorhyncha, Cyclorhagida) from Sri Lanka and of C. styx from Brazil, with notes on C. gerlachi from India and C. styx from Chile, and the ground pattern of the genus. Zootaxa, 2965 (1), 1-77. https://doi.org/10.11646/zootaxa.3965.1.1

Neuhaus, B., Schmid, T. \& Riedel, J. (2017) Collection management and study of microscope slides: Storage, profiling, deterioration, restoration procedures, and general recommendations. Zootaxa, 4322 (1), 1-173. https://doi.org/10.11646/zootaxa.4322.1.1

Neuhaus, B. \& Sørensen, M.V. (2013) Populations of Campyloderes sp. (Kinorhyncha, Cyclorhagida): One global species with significant morphological variation? Zoologischer Anzeiger, 252, 48-75. https://doi.org/10.1016/j.jcz.2012.03.002

Neuhaus, B., Dal Zotto, M., Yamasaki, H. \& Higgins, R.P. (2019) Revision of Condyloderes (Kinorhyncha, Cyclorhagida) including description of Condyloderes shirleyi sp. nov. Zootaxa, 4561(1), 1-91. https://doi.org/10.11646/zootaxa.4561.1.1

Neuhaus, B., Pardos, F., Sørensen, M.V. \& Higgins, R.P. (2014) New species of Centroderes (Kinorhyncha: Cyclorhagida) from the Northwest Atlantic Ocean, life cycle, and ground pattern of the genus. Zootaxa, 3901 (1), 1-69. https://doi.org/10.11646/zootaxa.3901.1.1

Pallares, R. (1966) Nota sobre Echinoderes pilosus Lang, 1949 (Aschelminthes, Kinorhyncha). Physis Revista de la Asociacion Argentina de Ciencias naturales, 26, 101-106.

Rundell, R.J. \& Leander, B.S. (2010) Masters of miniaturization: convergent evolution among interstitial eukaryotes. Bioessays, 32 (5), 430-437. https://doi.org/10.1002/bies.200900116

Sánchez, N., Sørensen, M.V. \& Landers, S.C. (2019) Pycnophyidae (Kinorhyncha: Allomalorhagida) from the Gulf of Mexico: Fujuriphyes viserioni sp. nov. and a redescription of Leiocanthus langi (Higgins, 1964), with notes on its intraspecific variation. Marine Biodiversity, 49, 1857-1875. https://doi.org/10.1007/s12526-019-00947-x

Spalding, M.D., Fox, H.E., Allen, G.R., Davidson, N., Ferdaña, Z.A., Finlayson, M., Halpern, B.S., Jorge, M.A., Lombana, A., Lourie, S.A., Martin, K.D., McManus, E., Molnar, J., Recchia, C.A. \& Robertson, J. (2007) Marine ecoregions of the world: a bioregionalization of coastal and shelf areas. BioScience, 57 (7), 573-583. https://doi.org/10.1641/B570707

Sørensen, M.V. \& Pardos, F. (2008) Kinorhynch systematics and biology—an introduction to the study of kinorhynchs, inclusive identification keys to the genera. Meiofauna Marina, 16, 21-73.

Sørensen, M.V., Heiner, I., Ziemer, O. \& Neuhaus, B. (2007) Tubulideres seminoli gen. et sp. nov. and Zelinkaderes brightae sp. nov. (Kinorhyncha, Cyclorhagida) from Florida. Helgoland Marine Research, 61, 247-265.

https://doi.org/10.1007/s10152-007-0073-8

Yamasaki, H. (2016) Two new Echinoderes species (Echinoderidae, Cyclorhagida) from Nha Trang, Vietnam. Zoological Stud- 
ies, $55,32,1-35$.

Yamasaki, H. (2017) Chapter 21. Diversity of Kinorhyncha in Japan and phylogenetic relationships of the phylum. In: Motokawa M, Kajihara, H (Eds.), Species diversity of animals in Japan. Diversity and commonality in animals. Springer, Tokyo, pp. 543-563.

https://doi.org/10.1007/978-4-431-56432-4_21

Yamasaki, H. (2019) Gracilideres mawatarii, a new genus and species of Franciscideridae (Allomalorhagida: Kinorhyncha) —a kinorhynch with thin body cuticle, adapted to the interstitial environment. Zoologischer Anzeiger, 282, 176-188. https://doi.org/10.1016/j.jcz.2019.05.010

Yamasaki, H. \& Dal Zotto, M. (2019) Investigation of echinoderid kinorhynchs described 90 years ago: redescription of Echinoderes capitatus (Zelinka, 1928) and Echinoderes ferrugineus Zelinka, 1928. Zoologischer Anzeiger, 282, 189-205. https://doi.org/10.1016/j.jcz.2019.05.013 